\title{
Entrepreneurial Versatility, Resources and Firm Performance in Russia: A Panel Study
}

\author{
By: Bat Batjargal
}

Working Paper Number 351

December 2000 
ENTREPRENEURIAL VERSATILITY, RESOURCES AND FIRM PERFORMANCE

IN RUSSIA: A PANEL STUDY

\author{
BAT BATJARGAL ${ }^{*}$ \\ Davis Center for Russian Studies \\ Harvard University \\ 1737 Cambridge Street \\ Cambridge, MA 02138 \\ Guanghua School of Management \\ Peking University \\ Beijing, 100871 \\ People's Republic of China \\ Tel: 86-10-6275 7763 \\ Email: bbat@gsm.pku.edu.cn
}

\footnotetext{
* I am grateful to the International Research \& Exchange Board (IREX) for its financial support for this research. IREX is not responsible for the views expressed herein. I would like to thank Joseph Berliner, Marshal Goldman, Sheila Puffer, Paul Reynolds and Anne Tsui for useful comments on the earlier versions of the paper.
} 


\title{
ENTREPRENEURIAL VERSATILITY, RESOURCES AND FIRM PERFORMANCE IN RUSSIA: A PANEL STUDY
}

\begin{abstract}
Drawing on the Upper-Echelons Perspective and Resource-Based View of the firm this paper explores effects of human-based resources of entrepreneurs, viz., social capital, human capital and entrepreneurial versatility, on firm performance in the context of a large transition economy - the Russian Federation. The empirical data is comprised of the face-to-face interviews with 75 Russian entrepreneurs in 1995 and the follow-up interviews with 56 original respondents in 1999. The finding suggests that entrepreneurial versatility have stronger positive impacts on firm performance in comparison to general human-based resources such as social capital and human capital.
\end{abstract}

KEY WORDS: Entrepreneurial versatility, resources, firm performance, Russia

\section{EXECUTIVE SUMMARY}

This study found that entrepreneurial versatility as an ability to predict resource needs and resource sequencing has positive impacts on firm performance. General human capital, i.e., industry and managerial experience, and social capital, i.e., extensive and diverse personal networks, have weaker effects on performance of entrepreneurial ventures. Although the context of the study is the transition economy of Russia, the findings may yield some practical implications for those who start businesses and those who manage new and mature businesses for better and stable performance. The ability to anticipate and structure what types of resources are needed, how much resources are needed, and when (in what sequencing order) resources are needed may lead to better assessments of entrepreneurial opportunities, and this enables entrepreneurs to formulate the right strategy to exploit recognised opportunities. Ingenuity to visualise resource needs also may reduce environmental uncertainties and harmful effects of external shocks. The research implies that entrepreneurs and managers should learn to predict what categories of resources are needed. This quality may enable entrepreneurs to substitute one type of resource that may be unavailable or costly by another type of resource that may be available and cheaper to be deployed. Entrepreneurs are advised to learn how to calculate resource (tangible and intangible) volumes. These skills may help to economise valuable and rare resources and reduce costs. Entrepreneurs are urged to develop the sense of timing or sequencing in resource deployment. While wrong sequencing of resource deployment may lead to waste of resources the accurate and stepped deployment may enable entrepreneurs to combine various kinds of resources creatively to get best performance indicators. For example, entrepreneurs may mobilise their own knowledge and experience to solve a certain business problem at the beginning. If they can not solve the issue they might approach their friends for advice and help. In case the contacts are unable to help out the entrepreneur may hire professional consultants who possess the necessary skills. In this case, human capital was deployed first (free and available), and then social capital (friends) was mobilised, and finally, financial resources were used to solve the problem. An important implication is that educational case studies on entrepreneurial resource prediction should be developed and used in training programmes. 


\section{INTRODUCTION}

A key question in management and entrepreneurship research is, Why some new ventures survive longer and grow at spectacular fast rates than others in the same contextual environment, e.g, industry or region. One of the popular explanations for performance diversity of entrepreneurial firms is the perspective of human-based resources of entrepreneurs and entrepreneurial teams. Human-based resources, i.e., skills, judgement and relationships (Barney, 1992, Barney \& Wright, 1998), are assumed to neutralise the liability of newness of entrepreneurial firms (Stinchcombe, 1965), enable entrepreneurs to marshal tangible resources and formulate and implement the right strategy in the right industry determining venture survival and growth. Previous studies, thus, found that personal networks (Aldrich, Rosen \& Woodward, 1987, Lerner, Brush \& Hisrich, 1997) and human capital of entrepreneurs and entrepreneurial teams (Bates, 1990, Bruderl, Preisendorfer \& Ziegler, 1992, Brush \& Chaganti, 1999, Chandler \& Hanks, 1998, Cooper \& Gimeno-Gascon, 1992) were positively associated with new venture longevity and eventual growth.

In addition and contrast to the previous studies of the new venture performance, in this paper, I argue that specific entrepreneurial resources, i.e., entrepreneurial versatility (Penrose, 1959: 36) have stronger and direct impacts on firm performance in comparison to general social and human capital resources such as networks or industry experience. In this study, I attempt to test propositions driven from the principal assumptions of the Upper Echelons Perspective (UEP) (Hambrick \& Mason, 1984) and Resource Based View of the firm (RBV) (Barney, 1991, Conner, 1991, Wernerfelt, 1984) on the interrelationships of personal resources of entrepreneurs and organisational performance in the context of a large transition 
economy - the Russian Federation.

It is hoped that this paper contributes to the existing literature in three ways: First, this research is one of the first scholarly studies that examines performance of Russian new ventures and privatised firms, and offers a systematic explanation of its variety. Second, by applying the UEP and RBV that were developed in the Western social context to the Russian reality, I expand the paradigms' boundaries to transition economies. Third, I demonstrate that human-based, specific entrepreneurial resources are likely to generate greater entrepreneurial rents than human-based, general resources such as social networks or education. In this way, I establish the hierarchy of the human-based resources of entrepreneurs in terms of its effects on firm performance.

\section{The Upper Echelons Perspective}

The Upper Echelons Perspective (Hambrick \& Mason, 1984) assumes that organisational outcomes - strategic choices and performance levels - are partially explained by managerial background characteristics. Age, cognitive ability, functional tracks, education, socioeconomic roots and financial position of top managers are regarded as factors that affect firm performance through mediating influences on strategic choices of firms.

Younger executive managers have more physical and mental stamina, and they are receptive to new ideas and information and less conservative in decision making, and these qualities may facilitate corporate growth (Child, 1974, Hart \& Mellons, 1970). Likewise, functional tracks of top managers also may influence firms' strategies: managers with marketing, sales and product R\&D experience emphasize outputs in its strategy whereas those with production and accounting background 
emphasize throughputs in its strategy (Hambrick \& Mason, 1984, Miles \& Snow, 1978). Socioeconomic background has also been theorised as a variable that affects firm performance: firms whose managers come from lower classes will experience greater growth and profit than will firms whose top managers come from higher socioeconomic groups (Hambrick \& Mason, 1984: 202).

Arguably, the assumptions of the Upper Echelons perspective are relevant to the context of new entrepreneurial ventures because founding entrepreneurs are often "the firm" at early stages of venture formation. Even at growth stages firms have "birth marks" of the characteristics of entrepreneurs because of the path dependence. In this perspective, social, demographic and personological attributions of the entrepreneur may explain diversities in venture performance (Shaver \& Scott, 1991).

\section{The Resource-Based View}

The Resource-Based View of the firm postulates that firms within an industry (or group) are heterogeneously endowed with strategic resources, and immobility of resources provides sustainable competitive advantage to those firms that possess and develop these resources (Barney, 1991, Wernerfelt, 1984). Three basic types of resources may provide competitive advantage (Barney, 1991). Physical capital resources include the firm's plant, equipment and finances. Organisational capital resources include firm's structure, planning, controlling, co-ordinating and HR systems. Human-based resources are knowledge, experience, skill, and commitment of a firm's employees and social relationships (Barney \& Wright, 1998: 32).

Intangible resources of firms that are socially-complex and embedded in human capital are likely to lead to rent generation only if they are valuable, rare, difficult-to-imitate and organised (VRIO framework) at the same time (Barney \& 
Wright, 1998). Valuable but common and easy-to-copy attributes of human resources provide only competitive parity, ensuring that a firm is not at a substantial competitive disadvantage because it does not possess that characteristics (Barney \& Wright, 1998: 34). Human-based resources, therefore, should have all four attributes in order to produce dynamic entrepreneurial capabilities that ensure sustainable competitive advantages (Alvarez \& Barney, 2000, Teece, Pisano \& Shuen, 1997).

In the main postulates of the RBV, resources are embedded in established organisations, and therefore, the standard carriers of resources are established firms and corporations. In the entrepreneurial context, however, an entrepreneur or entrepreneurial team may be regarded as resource carriers (Bamford, Dean \& McDougall, 1999, Chrisman, Bauerschmidt \& Hofer, 1998, Greene \& Brown, 1997, Mosakovski, 1998). The unit of analysis in the entrepreneurial context is an individual or group whose personal resources impact upon their firms' competitive advantage and performance. Resources of entrepreneurs exist as idiosyncratic and personalised collections of assets whereas firm resources are embedded in institutions as attributes of their structure, routines and culture.

Venkataraman (1998: 123) stated that enterprising individuals are different and these differences matter. Entrepreneurs vary in terms of endowment with tangible and intangible resources, and this difference may have significant but systematic impact on venture performance. The uneven pattern of resource dispersion among entrepreneurs at a given moment in time is a function of social structure (Stinchcombe, 1965). Different resources including knowledge are dispersed unevenly across the hierarchical as well as segmented groups in society (Hayek, 1945). This uneven resource dispersion is referred to the resource heterogeneity of entrepreneurs. The resource heterogeneity forms the set 
of constraints that governs the functioning of society in a durable way determining the chances of success for instrumental actions of individuals, e.g., entrepreneurs (Bourdieu, 1986).

The resource heterogeneity of entrepreneurs is bi-dimensional: the resource asymmetry dimension and the resource diversity dimension. The resource asymmetry refers to the fact that individuals across the social hierarchy hold uneven resources and capabilities (Anheier, Gerhards \& Romo, 1995). The resource diversity means the different instrumental value of resources. The former refers to the fact that individuals as members of various groups possess different kinds of resources. The latter means that the volume and kind of services obtainable from each category of resource is different (Penrose, 1959), and thus, different classes of resources have asymmetric convertible power in gaining more resources or to be exchanged in commercial transactions.

A key difference among individual entrepreneurs is the difference in endowment with human-based resources: entrepreneurs differ in terms of specific knowledge, cognitive ability and behavioural propensity (Venkataraman, 1998: 123). Unique knowledge, creative talent and entrepreneurial aptitude of the upper-echelons (Hambrick \& Mason, 1984) are likely to be valuable, rare and hard-to-imitate (Barney \& Wright, 1998) and therefore, may influence strongly the relative success of the entrepreneurial process.

In this study, I focus on how heterogeneity in knowledge, cognitive ability and social behaviour of entrepreneurs as the upper echelons of firms influences organizational performance. Knowledge heterogeneity means the difference in general human capital such as education and experience (Becker, 1975). Heterogeneity in cognitive ability refers to the difference in a specific entrepreneurial ability such as 
the entrepreneurial versatility (Penrose, 1959: 36). Heterogeneity in social behaviour refers to the difference in entrepreneurial networking, i.e., social capital. Heterogeneity in social capital is the uneven endowment with social resources that are linked to possession of durable connections of mutual friendship, acquaintance and recognition (Bourdieu, 1986, Burt, 1997, Coleman, 1988).

Penrose (1959: 36) provided the definition of entrepreneurial versatility as the instinctive recognition of what will catch on or how to make it catch on, and the sense of timing. It is referred to a specific entrepreneurial resource the limited volume of which may restrict firm growth (Penrose, 1959). I operationalise entrepreneurial versatility as the ability to predict the ways in which various resources are required and when required in the entrepreneurial process. Entrepreneurs that possess this quality are assumed to have a wide range of opportunities and choices than those with less entrepreneurial versatility (Mosakowski, 1998, Penrose, 1959).

Entrepreneurial opportunities are embedded in certain situations and these situations exist as structured parts of the world discriminated and individuated by entrepreneurs within spatial and temporal locations. The discrimination process structures and internalises the resource demand of an opportunity by identifying what resource is needed how much, and links the entrepreneurs' vision with real existing opportunities. Any opportunity has a temporal location, and therefore, it requires a certain sequence or timing order of resource deployment. Sequenced resource deployment is a stepped, multi-staged commitment of resources in such an order that it matches the temporal need of each entrepreneurial situation. The entrepreneurial versatility, therefore, has two dimensions: (i) the ability to recognise instinctively what resources are needed how much; (ii) the intuition to anticipate when a certain type of 
resource is required, i.e., the sense of sequencing of resource deployment.

\section{The Russian Context}

The structure of status attainment in Soviet Russia, arguably, was unidimensional: political power played the predominant role for favourable outcomes of instrumental actions (Shkaratan \& Figatner, 1992). Other resources such as wealth, connections and education had been of secondary importance in comparison to political power. With the transition to market economy leverages for instrumental actions in Russia are becoming multi-dimensional (Kosova, 1999). Political power has lost its former "absolute might" although it clearly remains one of the most useful assets (Kryshtanovskaya \& White, 1996). Wealth is gaining new grounds as the mightiest resource in its utilitarian value. Social and human capital are increasingly becoming instrumental assets in the disoriented, chaotic transition (Zaslavskaya, 1997). The uneven pattern of resource distribution in Russian society endows some entrepreneurs with larger and diverse resources but puts other entrepreneurs at disadvantage. The pre-transition resource heterogeneity of individuals and subsequent changes in the utilitarian value of resources, thus, creates the resource heterogeneity among Russian entrepreneurs.

\section{HYPOTHESES}

\section{Social Capital}

Research findings on effects of networks on venture performance were mixed despite conclusions about its vitality for entrepreneurial success (Aldrich \& Zimmer, 1986, Birley, 1985, Burt, 1992, Larson, 1992, Nohria, 1992). The presence of networks and its low density were found to increase the profitability of new ventures (Aldrich, Rosen \& Woodward, 1987, Lerner, Brush \& Hisrich, 1997). Reese \& 
Aldrich (1995), however, found no evidence to suggest that the network size and the amount of time invested in developing a network affects business survival.

It is assumed, however, that extensive networks enable entrepreneurs to locate clients and suppliers who are socially bound. This may facilitate sales stabilization and eventual growth since the embeddedness provides a flexible room for negotiations that might allow entrepreneurs to convert the social bonds into revenue growth. The personal chemistry between the entrepreneur and the supplier is likely to enable the entrepreneur to purchase raw materials and other production inputs at stable prices, and that might positively influence profit margin. There is empirical evidence that personalized relations between entrepreneurs and their bankers lead to cheaper interest rates on loans (Uzzi, 1999), and spin-off firms get favourable rates on equipment leasing from their parent companies (Webster \& Charap, 1993). These arrangements may improve firm's financial performance ratios such as return on assets.

Diverse networks are conducive to interactions of entrepreneurs with others of different attributes. Bankers may be able to build a broad range of clients' base with differentiated needs across different industries, and this may enable them to customize their products building customer loyalty and spread risks of defaults. In this way, bankers are likely to build customers' dependence that may enhance their client retention and wallet penetration capabilities. Trading firms may get better access to overdraft facilities, speedy cash management and other services from embedded relationships with bankers whereas production firms may deliver goods in time and be flexible to ad hoc customer demands. Diversity of contacts may be crucial for manufacturing firms in the Russian conditions: the wide-spread phenomenon of interenterprise arrears and barter exchanges that plagued the Russian economy ever since 
the late 1980s (Dolgopyatova, 1995) may have forced Russian manufacturers to diversify their networks in order to survive. The simple production chain of resource firms makes them less reliant on personal relations with managers of trading or manufacturing firms although they are likely to gain negotiated rates from bankers on services such as foreign currency exchange or international money transfer and etc. The available empirical evidence supports the proposition that firms in transition economies enter and build deliberately a complicated web of interconnected firms where assets and liabilities are creatively dispersed in order to reduce the harming effects of environmental uncertainties (Sedaitis, 1998, Stark, 1996).

Hypothesis 1: Social capital of entrepreneurs is positively related to firm performance.

\section{Human Capital}

Prior research on the relationship between general human capital of entrepreneurs and firm performance produced positive associations in general. The literature review by Cooper and Gimeno-Gascon (1992) reported that 10 of 17 earlier studies had found positive relationships between education and firm performance. Years of schooling, managerial and industry experience were correlated with new venture survival and positive cash flows (Bruderl, Preisendorfer \& Ziegler, 1992, Brush \& Chaganti, 1999).

Industry experience enable entrepreneurs to understand better the regulatory framework of the industry, analyse the industry structure and dynamics and possess market and product knowledge. Those who worked in the industry before are likely be alert to new opportunities created by regulatory changes. Industry knowledge will be vital for identification of the strengths and weaknesses of major competitors that would enable firms to have the right strategic positioning. Knowledge of product 
quality and range is likely to lead to the right marketing and pricing policy that may increase revenue.

Entrepreneurs that worked as managers are likely to have greater ability to lead and set up better organisation routines and HR policies. In this way, managerial experience and tacit knowledge are assumed to influence positively firms' performance indicators. The empirical evidence from Russia suggests that the Soviet enterprise directorship and industry experience, viz., banking, found to enhance performance of new ventures and privatised firms (Bunin, 1994).

Hypothesis 2: Human capital of entrepreneurs is positively related to firm performance.

\section{Entrepreneurial Versatility}

Developing new markets, expansion of product range and output in spite of unfavourable market conditions is a function of versatile type of entrepreneurial leadership (Penrose, 1959). Versatile services are not likely to be equally available to all firms. The deficit of entrepreneurial instincts to anticipate the resource need volume and type - of an opportunity may lead to eventual failure whereas the presence of ingenuity to individuate what opportunities may catch on and how they are internally structured and sequenced may enable entrepreneurs to maximize profits.

There is virtually no systematic study that examines effects of entrepreneurial versatility on performance. Ethnographic studies in Russia, however, seems to suggest that small firms grow in this hostile environment, for the most part, by virtue of a special entrepreneurial ability. The case studies by Khait, Suvorova \& Ageev (1997) found that the majority of Russian companies that increased their revenue have creative and visionary leaders who anticipate new opportunities and act upon them. Oleg Kiselev, chairman of MOSEXPO, a large trading company in Moscow, said: 
"Svyazi (connections) within the academic community themselves will not be very useful for business. Therefore, I have to look for connections with those who distribute resources. No matter how far-reaching your connections, they do not always give you the outcome that you were looking for. So you have to look for various ways, channels and assets to get deals done in Russia" (Author's interview, May 1995, Moscow). The example substantiates the importance of prediction of network and political power as resources in Russian entrepreneurship. It is assumed, therefore, that the ability to anticipate resource needs is the factor that governs why one of the two entrepreneurs endowed with similar volumes of resources succeeds and the other does not.

Hypothesis 3a: Entrepreneurial versatility is positively related to firm performance.

Hypothesis 3b: Entrepreneurial versatility has a stronger positive impact on firm performance than human capital and social capital of entrepreneurs.

\section{METHODOLOGY}

\section{Sample and Data Collection}

The empirical data of the study is composed of the face-to-face interviews with 75 Russian entrepreneurs in February-June 1995, and the follow-up interviews with 56 original respondents in March-May 1999. Pilot interviews with six Moscow firms were conducted in August 1994.

In 1995, I selected firms on the basis of a stratified random sampling procedure in three Russian cities, viz., Moscow, Ekaterinburg and Petrozavodsk. The computerised database of registered businesses of the Moscow City Committee of Statistics, Business Assistance Centre of the Sverdlovsk Regional Administration in Ekaterinburg, and the State Committee of Statistics of the Republic of Karelia in 
Petrozavodsk were used as sampling populations. I created twelve lists of firms (four industries and three sizes) each of which contained twenty firm names.

Banks were classified in accordance with the following criteria: small charter funds < US\$50 000, medium charter funds US\$50 001-250 000, and large charter funds > US $\$ 250001$. This grouping was confirmed in interviews with Russian experts and Central bank officials. A similar classification has been established in another study of Russian banks (Lapidus \& van de Waal-Palms, 1997). In manufacturing and the resource sector, firms were grouped: small $-<100$ employees, medium - 101-500 employees, and large - > 501 employees. Trade firms were classified: small $-<50$ employees, medium - 51-200 employees, and large - > 201 employees. The classification is based on the definition of small firms in the Russian law and discussions with Russian experts (Rossiiskaya federatsiya, 1995).

Every second firm on these lists was selected for contact. In 1995, 120 entrepreneurs were contacted and 82 agreed to be interviewed. The response rate was 68 percent. 7 respondents were discovered as ineligible in the field, so that the final sample consisted of 75 entrepreneurs and directors. There were 50 new ventures and 25 privatized companies. Interviews were conducted with a specially designed questionnaire that contained questions on entrepreneurial networks and firm characteristics. In 1999, I re-interviewed 56 original respondents.

Insert Tables 1 and 2 about here

Performance data was obtained from firms as well as other sources such as the Central Bank of Russia, Association of Russian Banks, the Foundation for Small Business Development in three cities, and local tax offices. About a half of the sample firms provided annual reports that contained accounting information. In most 
occasions, financial directors or chief accountants were interviewed additionally on financial issues. The reliability and consistency of company financial statements still remains questionable in Russia although significant progress has been made for the last few years to bring Russian accounting practices in the line with the Western standard.

\section{Dependent Variable}

The dependent variable is firm performance. Organisational performance may be measured in various ways (March \& Sutton, 1997, Meyer, 1994). In this study, I adopt average revenue growth for 1996, 1997 and 1998 as the indicator for firm performance.

\section{Independent Variables}

Independent variables are social capital, human capital and entrepreneurial versatility.

Social capital is measured by network size and network heterophily. Network size is defined as the number of direct ties involving individual units (Marsden, 1990, Moore, 1990). Network size is measured by the number of ties indicated by respondents. I presented a table where the following fifteen types of occupations were listed in rows: CPSU, Komsomol (Young Communist League), Union secretary and official, Ispolkom (Soviet local government) chairman and official, official in ministries, officer in the Soviet army, KGB and police, official in Gosplan (State Planning Agency) and Gossnab (State Supply Agency), enterprise director, banker, trade sector employee, university lecturer, doctor, cultural worker, engineer and second economy entrepreneur. Two types of tie strength, i.e., friendship and acquaintance, were placed in columns (Lin \& Dumin, 1986). I asked the respondents 
to indicate how many people were in each cell.

Network heterophily refers to the degree which an ego network contains diverse alters, e.g., demographic characteristics or occupational status (Ibarra, 1993, Marsden, 1987, Renzulli, Aldrich \& Moody, 1999). Network heterophily measures the degree to which an egocentric network contains alters from industries other than the respondent's own occupational background. Entrepreneurs were grouped into five categories by occupational background: (i) party and state bureaucracy; (ii) enterprise directors; (iii) engineer and shop floor managers; (iv) research scientists; (v) others. Heterophily captures the proportion of non-industry contacts within the total number of ties.

Human capital. Entrepreneurs' human capital is measured by industry experience and managerial experience. Each variable is a binary variable of one if the respondent has experience and zero if the respondent has no experience.

Entrepreneurial versatility. Proxies for entrepreneurial versatility are prediction of financial resources' needs, prediction of social resources' needs, prediction of human resources' needs, prediction of finance sequencing, prediction of social capital sequencing and prediction of human capital sequencing.

Prediction of resource needs is measured by matching between the need of a certain resource at the start-up stage and the actual deployment of the resource in the process of venture development (Light \& Rosenstein, 1995). In 1995 interviews I asked two questions to identify the demand for a particular resource: First, please describe the entrepreneurial opportunity you perceived when you started the business (the company was privatised)? What kinds of resources, e.g., money or connections, the opportunity demanded? The question was asked to let the respondent to 
conceptualise the resource demand of the opportunity and prepare for the next closeended question. Afterwards, I displayed a table that contained a list of resources, i.e., finance, network and human capital, in rows, and three levels of resource demand, i.e., "much needed", "needed", and "less or not needed", in columns, and asked to tick the appropriate cell for each resource. Thus, resource need at the start-up stage was identified.

A female entrepreneur-shop owner in Ekaterinburg responded to the openended question: "In order to buy this small shop we sold our old car, rented out dacha (country house), and borrowed money from my brother-in-law. Then we bought it. It was not difficult because the shop was in a terrible condition and nobody wanted it anyway. However, soon after the deal when we tried to obtain consumer goods for sale our "khozhdenie po mukam" (going through sufferings) started. It was so difficult that besides money you have to have powerful connections, and you should know whom to approach among local bureaucrats and when and how to bribe them. In short, we were so fed up with these complicated rules that we wanted to give up once. Now everything is stable, and we know how to operate in this environment." (Author's interview, April 1995, Ekaterinburg).

In 1999 interviews, I asked respondents to rank the three types of resources (finance, network and human capital) to the extent they were - "much used", "used", and "less or not used". After the follow-up study, I matched the resource need at the start-up stage and deployment in the process of new venture development. Variables are binary of one if "much needed" matches "much used", "needed" matches "used" and "less needed" matches "less used", and the rest is zero denoting mismatch.

Prediction of resource sequencing was measured by matching between the 
resource sequencing need and the actual sequencing of resource deployment. In 1995 interviews I asked: How did you start? What was your first step? Have you contacted your friends for advice first or you started to raise money? Then, I asked to order resources (finance, network and human capital) in terms of sequence they were needed: "first needed", "second needed", "third needed", "fourth needed", and "fifth needed". In 1999 follow-up interviews, I asked to indicate the sequence of resource deployment: "first used", "second used", "third used", "fourth used", and "fifth used". Finally, I matched the sequence need at the start-up stage and the actual sequencing. Variables are binary of one if "first needed" matches "first used", "second needed" matches "second used", "third needed" matches "third used", "fourth needed" matches "fourth used", "fifth needed" matches "fifth used", and the rest is zero denoting mismatch.

\section{Control Variables}

Industry (banking, trade, manufacturing, and the resource sector), firm size (large, medium and small), firm age, region (Moscow, Ekaterinburg, and Petrozavodsk) and firm origin (new venture versus privatised) were controlled in this study. Three cities represent Russia's regional economic diversity well. Moscow is the financial and commercial centre whereas Ekaterinburg is famous for its heavy industry. The timber industry and trade is highly developed in Petrozavodsk, the capital city of the Republic of Karelia,

\section{RESULTS}

\section{Descriptive Statistics}

The performance indicator in Table 3 shows that Russian firms performed very poorly: the average revenue growth for three years was about two percent (s.d. = 
0.33). The mean network size was 82 persons $($ s.d. $=24.25)$. The mean heterophily was 78 percent $($ s.d. $=0.13)$. About two-third of the respondents $(59$ percent, s.d. $=$ 0.49) had managerial experience whereas almost a half (46 percent, s.d. $=0.50)$ worked in the same industry.

Insert Table 3 about here

More than 50 percent of the respondents were able to anticipate accurately needs of financial $($ s.d. $=0.50)$, social $($ s.d. $=0.57)$, and human resources $($ s.d. $=0.49)$. If 57 percent (s.d. $=0.49)$ of the entrepreneurs knew when to deploy their social assets to get things done, only one-third $($ s.d. $=0.30)$ predicted the correct sequencing of financial resources. The average firm age appeared 9.32 years $($ s.d. $=11.12)$ because of the lengthy ages of privatised firms.

\section{Firm Performance}

Table 4 provides the results of multivariate regression predicting firm performance as a function of social capital, human capital and entrepreneurial versatility, controlling for industry, region, firm size, age and origin.

Insert Table 4 about here

The baseline model (1) includes industry, size, origin, region dummies and age. Resource sector dummy, Petrozavodsk dummy, medium size dummy and privatised dummy were excluded in the regression analysis due to their weak contributions to the models. Model 2 shows the effects of social capital on revenue growth: neither network size $(B=-0.00)$ nor heterophily $(B=0.68)$ are significantly related to revenue growth. The model is not significant. Model 3 indicates that two human capital variables (industry experience, $\mathrm{B}=0.18$, and managerial experience, $\mathrm{B}=0.00$ ) have no 
impacts on revenue growth. The model is not significant. Models 4-5 report the effects of entrepreneurial versatility on firm performance. Model 4 demonstrates that prediction of social resources $(B=0.28, \mathrm{p}<0.01)$ and prediction of human resources $(\mathrm{B}=0.25, \mathrm{p}<0.01)$ are positively and significantly correlated to revenue growth whereas prediction of financial resources $(B=0.04)$ has no impact on firm performance. The overall model is significant $\left(\mathrm{F}=3.44, \mathrm{R}^{2}=0.51\right)$. Model 5 reveals that only prediction of financial sequencing $(B=0.46, p<0.01)$ positively and significantly affects sales growth in contrast to prediction of social capital sequencing $(B=0.17)$ and prediction of human capital sequencing $(B=0.00)$. The overall model is significant $\left(\mathrm{F}=2.08, \mathrm{R}^{2}=0.39\right)$. Model 6 examines the effects of all independent variables and control dummies simultaneously on sales growth. The model suggests that network heterophily $(B=0.74, p<0.05)$, industry experience $(B=0.29, p<0.05)$ and prediction of human resources $(B=0.20, \mathrm{p}<0.05)$ have positive impacts on firm performance. The overall model is also significant $\left(F=3.34, \mathrm{R}^{2}=0.66\right)$.

\section{DISCUSSION}

It appears that extensive personal networks are not conducive to better sales records whereas network heterophily positively influences revenue growth. Hypothesis 1 that proposed positive relationships between performance and social capital, therefore, has only been partially confirmed. The social and institutional chaos in Russia that creates the low-trust society where people do not trust and co-operate may explain the lack of any effects of network size on performance. The absence of control mechanisms and high cost of monitoring for agency in extensive contacts is also a reason for the insignificance of network size for performance. The finding is consistent with the fact that Russians were three times less likely to co-operate than 
Poles and Bulgarians (Pilikhovskii \& Stolbov, 2000). Contacts with people from other industries seem to provide tangible and intangible benefits that boost revenue growth.

Human capital viz., industry and managerial experience, have mixed impacts on sales increase. Industry knowledge appears useful though the dynamics of industries in planned and market economies do differ sharply. This finding supports the qualitative evidence from Russia that industry related resources increase the likelihood of firm growth (Bunin, 1994). Soviet managerial experience has a negative effect on performance although it is statistically insignificant. Leadership skills and organisational routines learned in the centrally planned economies where the main duty of managers was to carry out the Communist party's orders appeared obsolete and harmful for entrepreneurial performance in market conditions. The finding questions the empirical validity of the argument that enterprise director experience may provide some advantages for former "red" executives (Eyal, Szelenyi \& Townsley, 1997).

The findings on entrepreneurial versatility tentatively confirm hypotheses $3 \mathrm{a}$ and 3b. Entrepreneurial versatility as a valuable, unique and hard-to-imitate resource leads to greater rent generation in post-Soviet Russia. Entrepreneur's skills to recognise what types of resources are needed how much and in what order they are needed prove to be the survival "tools" for Russian firms. Moreover, the talent to visualise what opportunities will catch on and what resources will be required appears as the engine for entrepreneurial growth in Russia. Entrepreneurial versatility as a resource, thus, has stronger predicting power for firm performance in comparison to general social and human capital. 


\section{CONCLUSION}

The main argument of the study that human-based resources of the upper echelons of firms - in particular, entrepreneurial versatility - affect entrepreneurial performance has an empirical ground in the context of the transition economy of Russia. Arguably, the story that the presence of entrepreneurial versatility partially explains firm performance indicates the importance of human ingenuity and talent in all types of economy. In this sense, entrepreneurial versatility has a universal value not contingent upon context. The evidence provides an empirical ground for a postulate of the growth theory of the firm proposed by Penrose (1959) that firm growth occurs and sustains only if entrepreneurs are versatile enough to lead to growth.

Several limitations of the study should be emphasised. The sample size is relatively small, and therefore, one should be cautious of over-generalisation of the results. Operationalisation of core variables and their measurements, e.g., entrepreneurial versatility, are "rough" proxies. This may weaken the explanatory power of the argument that entrepreneurial versatility impacts firm performance more than other human-based resources. Company performance influencing variables such as strategy, were not incorporated in the model and therefore, the study may have over-emphasised the effects of human-based intangible resources.

The research implies that entrepreneurial versatility as a variable requires a more robust conceptualisation and precise operationalisation and measurements for further research. The research implies that entrepreneurs and managers should learn to predict what categories of resources are needed. This quality may enable entrepreneurs to substitute one type of resource that may be unavailable or costly by another type of resource that may be available and cheaper to be deployed. Entrepreneurs are advised 
to learn how to calculate resource (tangible and intangible) volumes. These skills may help to economise valuable and rare resources and reduce costs. Entrepreneurs are urged to develop the sense of timing or sequencing in resource deployment. While wrong sequencing of resource deployment may lead to waste of resources the accurate and stepped deployment may enable entrepreneurs to combine various kinds of resources creatively to get best performance indicators. 


\section{REFERENCES}

Aldrich, H. \& Zimmer, C. 1986. Entrepreneurship through social networks. In D. Sexton and R. Smilor, (Eds.), The art and science of entrepreneurship: 3-23. Cambridge, Mass: Ballinger Publishing.

Aldrich, H. Rosen, B. \& Woodward, W. 1987. The impact of social networks on business foundings and profit: A longitudinal study. In N. Churchill, J. et al. (Eds.), Frontiers in entrepreneurship research: 154-168. Wellesley, Mass: Babson College.

Alvarez, S. \& Barney, J. 2000. Entrepreneurial capabilities, A resource-based view. In D. Meyer \& K. Heppard, (Eds.), Entrepreneurship as strategy, Competing on the entrepreneurial edge: 63-82. London: Sage Publications.

Anheier, H. Gerhards, J. \& Romo, F. 1995. Forms of capital and social structure in cultural fields: Examining Bourdieu's social topography. American Journal of Sociology, 100 (4): 859-903.

Bamford, C. Dean, T. \& McDougall, P. 1999. An examination of the impact of initial founding conditions and decisions upon the performance of new bank start-ups. Journal of Business Venturing, 15: 253-277.

Bates, T. 1990. Entrepreneurial human capital inputs and small business longevity. Review of Economics and Statistics, 72: 551-559.

Barney, J. 1991. Firm resources and sustained competitive advantage. Journal of Management, 17: 99-120.

- 1992. Integrating organizational behavior and strategy formulation research: A resource based analysis. Advances in Strategic Management, 8: 39-61.

— \& Wright, P. 1998. On becoming a strategic partner: The role of human resources in gaining competitive advantage. Human Resource Management, 37 (1): 31-46.

Becker, G. 1975. Human capital. New York: National Bureau of Economic Research.

Birley, S. 1985. The role of networks in the entrepreneurial process. Journal of Business Venturing, 1(1): 107-117.

Bourdieu, P., 1986. The forms of capital. In J. Richardson, (Ed.), Handbook of Theory and Research for the Sociology of Education: 241-258. New York: Greenwood.

Bruderl, J. Preisenorfer, P. \& Ziegler, R. 1992. The survival chances of newly founded business organisations, American Sociological Review, 57: 227-242.

Brush, C. \& Chaganti, R. 1999. Businesses without glamour? An analysis of resources on performance by size and age in small service and retail firm. Journal of Business Venturing, 14: 233-257. 
Bunin, I. 1994. Biznesmeny Rossii 40 istorii uspekha, Moscow.

Burt, R. 1992. Structural holes, the social structure of competition. Cambridge, Mass: Harvard University Press.

- 1997. The contingent value of social capital. Administrative Science Quarterly, 42: 339-365.

Coleman, J. 1988. Social capital in the creation of human capital. American Journal of Sociology, 94: S95-S120.

Conner, K. 1991. A historical comparison of resource-based theory and five schools of thought within industrial organization economics: Do we have a new theory of the firm?. Journal of Management, 17: 121-154.

Chandler, G. \& Hanks, S. 1998. An examination of the substitutability of founders human and financial capital in emerging business ventures. Journal of Business Venturing, 13: 353-369.

Child, J. 1974. Managerial and organisational factors associated with company performance. Journal of Management Studies, 11: 13-27.

Chrisman, J. Bauerschmidt, A. \& Hofer, C. 1998. The determinants of new venture performance: An extended model. Entrepreneurship: Theory and Practice, Fall: 5-29.

Cooper, A. \& Gimeno-Gascon J. 1992. Entrepreneurs, processes of founding, and new firm performance. In D. Sexton, \& J. Kasarda, (Eds.), The State of the art of entrepreneurship: 301-340. Boston: PWS-Kent publishing.

Dolgopyatova, T. 1995. Rossiiskie predpriyatiya V perekhodnoi ekonomike, ekonomicheskie problemy i povedenie, Moscow: Delo.

Eyal, G. Szelenyi, I. \& Townsley, E. 1997. The theory of post-communist managerialism. New Left Review, 222: 60-92.

Greene, P. \& Brown, T. 1997. Resource needs and the dynamic capitalism typology. Journal of Business Venturing, 12: 161-173.

Hambrick, D. \& Mason, P. 1984. Upper echelons: The organisation as a reflection of its top managers. Academy of Management Review, 9 (2): 193-206.

Hart, P. and Mellons, J. 1970. Management youth and company growth: A correlation? Management Decision, 4(2): 50-53.

Hayek, F. 1945. "The use of knowledge in society." American Economic Review. 35: 519-530.

Ibarra, H. 1993. Personal networks of women and minorities in management: a conceptual framework. Academy of Management Review, 18 (1): 56-87 
Khait, I. Suvorova, I. \& Ageev, S. 1997. Menedzhment rosta. Marketing i marketingovye issledovaniya, 2(8): 37-60.

Kosova, L. 1999. Den'gi ili vlast'? Monitoring obshchestvennogo mneniya, 41 (3): 24-26.

Kryshtanovskaya O. \& White, S. 1996. From Soviet nomenklatura to Russian elite. Europe-Asia Studies, 48(5): 711-733.

Lapidus, M. \& van de Waal-Palms, P. 1997. Understanding Russian banking, Mir.

Larson, A. 1992. Network dyads in entrepreneurial settings: A study of the governance of exchange relationships. Administrative Science Quarterly, 37: 76-104.

Lerner, M. Brush, C. \& Hisrich, R, 1997. Israeli women entrepreneurs: An examination of factors affecting performance. Journal of Business Venturing, 12: 315339.

Light, I. \& Rosenstein, C, 1995. Expanding the interaction theory of entrepreneurship. In A. Portes, (Ed.), The economic sociology of immigration: 166-212. New York: Russel.

Lin, N. \& Dumin, M. 1986. Access to occupations through social ties. Social Networks, 8: 365-385.

March J. \& Sutton, R. 1997. Organizational performance as a dependent variable. Organization Science, 8(6): 698-706.

Marsden, P. 1987. Core discussion networks of Americans. American Sociological Review, 52: 122-131.

- 1990. Network data and measurement. Annual Review of Sociology, 16: 435-463.

Meyer, M. 1994. Measuring performance in economic organizations. Pp. 556-578. The Handbook of Economic Sociology edited by Neil Smelser \& Richard Swedberg. Princeton: Princeton University Press.

Miles, R. \& Snow, C. 1978. Organization strategy, structure and process, New York: McGraw-Hill.

Moore, G. 1990. Structural determinants of men's and women's personal networks. American Sociological Review, 55: 726-735.

Mosakowski, E. 1998. Entrepreneurial resources, organizational choices and competitive outcomes. Organization Science, 9(6): 625-643.

Nohria, N. 1992. Information and search in the creation on new business ventures: the case of the 128 venture group, Pp. 240-261. Networks and organizations: Structure, form, and action, edited by N. Nohria \& R. Eccles, Boston: Harvard Business School 
Penrose, E. 1995. The theory of the growth of the firm, Oxford: Oxford University Press.

Pilikhovskii, A. \& Stolbov, V. 2000. Neformal'naya kooperatsiya v sel'skikh obshchinakh: na primere Polshi, Rossii, Bolgarii. Sotsis, 1: 34-36.

Reese, P. \& Aldrich, H. 1995. Entrepreneurial networks and business performance: A panel study of small and medium-sized firms in the research triangle. In S. Birley, and I. Macmillan, (Eds.), International Entrepreneurship: 124-146. London: Routledge.

Renzulli, L. Aldrich, H. \& Moody, J. 1999. Family matters: Gender, networks, and entrepreneurial outcomes, Manuscript. Department of Sociology, University of North Carolina at Chapel Hill.

Rossiiskaya federatsiya. 1995. Zakon o gosudarstvennoi podderzhke malogo predprinimatel'stva, Moscow.

Sedaitis, J. 1998. The alliances of spin-offs versus start-ups: Social ties in the genesis of post-Soviet alliances. Organization Science 9 (3): 368-381.

Shaver, K. \& Scott, L. 1991. Person, Process, Choice: The Psychology of New Venture Creation. Entrepreneurship: Theory and Practice, Winter: 23-45.

Shkaratan, O. \& Figatner, Yu. 1992. Starye i novye khozyaeva Rossii Mir Rossii, 1(1): 67-90.

Stark, D. 1996. Recombinant property in East European capitalism. American Journal of Sociology 101 (1): 993-1027.

Stinchcombe, A. 1965. Social structure and organisations. In J. March, (Ed.), Handbook of organisations: 142-193. Chicago: Rand McNally.

Teece, D. Pisano, G \& Shuen, A. 1997. Dynamic capabilities and strategic management, Strategic Management Journal, 18(7): 509-533.

Uzzi, B. 1999. Embeddedness in the making of financial capital: How social relations and networks benefit firms seeking financing American Sociological Review, 64: 481-505.

Venkataraman, S. 1998. The Distinctive domain of entrepreneurship research. In J. Katz, (Ed). Advances in entrepreneurship research, firm emergence, and growth, 3: 119-138, JAI Press.

Webster, L. \& Charap, J. 1993. The emergence of private sector manufacturing in St. Petersburg:, Technical paper no. 228, Washington D. C: the World Bank.

Wernerfelt, B. 1984. A resource-based view of the firm. Strategic Management Journal, 5: 171-180. 
Zaslavskaya, T. 1997. Sotsial'naya struktura sovremennogo rossiiskogo obshchestva. Rossiya i sovremennyi mir, 4: 5-23. 
TABLE 1

The Number of Entrepreneurs Interviewed in 1995

\begin{tabular}{|c|c|c|c|c|c|c|}
\hline & & \multicolumn{4}{|c|}{ Industry } & \multirow{2}{*}{ Total } \\
\hline & & Banking & Trade & Manufac. & $\begin{array}{l}\text { Resource } \\
\text { sector }\end{array}$ & \\
\hline \multirow{4}{*}{$\begin{array}{l}\text { Moscow Size: } \\
\end{array}$} & & 7 & 9 & 12 & 2 & 30 \\
\hline & Large & 6 & 4 & 3 & 1 & 14 \\
\hline & Medium & 1 & 2 & 2 & 1 & 6 \\
\hline & Small & - & 3 & 7 & - & 10 \\
\hline $\begin{array}{l}\text { Ekaterinburg } \\
\text { Size: }\end{array}$ & & 10 & 4 & 6 & 3 & 23 \\
\hline \multirow{6}{*}{$\begin{array}{l}\text { Petrozavodsk } \\
\text { Size: }\end{array}$} & Large & 4 & 1 & 4 & 1 & 10 \\
\hline & Medium & 2 & 1 & 1 & 1 & 5 \\
\hline & Small & 4 & 2 & 1 & 1 & 8 \\
\hline & & 5 & 8 & 4 & 5 & 22 \\
\hline & & 1 & 1 & 1 & 3 & 6 \\
\hline & Medium & 2 & 5 & 2 & 2 & 11 \\
\hline \multirow[b]{2}{*}{ Total } & Small & 2 & 2 & 1 & - & 5 \\
\hline & & 22 & 21 & 22 & 10 & 75 \\
\hline
\end{tabular}

TABLE 2

Follow-up Interviews in 1999

\begin{tabular}{llc}
\hline & "Location" after 4 years & \\
\hline No-Contact: & Murdered & 9 \\
& Committed suicide & 2 \\
& Left the country & 1 \\
& Hiding from criminal charges & 2 \\
& Unreachable & 2 \\
& & 2 \\
Not in Business: & Hired middle managers & 7 \\
& Civil servant & 2 \\
& Local politician & 1 \\
& Unemployed & 1 \\
& Retired & 1 \\
& & 1 \\
In Business: & Refusal & 59 \\
& Interviewed & 3 \\
& & 56 \\
\hline
\end{tabular}


TABLE 3

Means, Standard Deviations and Pearson's Correlations

\begin{tabular}{|c|c|c|c|c|c|c|c|c|c|c|}
\hline & & $\mathbf{M}$ & S.D. & 1 & 2 & 3 & 4 & 5 & 6 & 7 \\
\hline 1 & Network size & 82 & 24.25 & & & & & & & \\
\hline 2 & Network heterophily & 0.78 & 0.13 & -.04 & & & & & & \\
\hline 3 & Industry experience & 0.46 & 0.50 & -.01 & -.04 & & & & & \\
\hline 4 & $\begin{array}{l}\text { Managerial } \\
\text { experience }\end{array}$ & 0.59 & 0.49 & -.14 & $.34 \mathbb{I}$ & .04 & & & & \\
\hline 5 & $\begin{array}{l}\text { Prediction of } \\
\text { financial resources }\end{array}$ & 0.50 & 0.50 & .18 & .01 & .10 & -.21 & & & \\
\hline 6 & $\begin{array}{l}\text { Prediction of social } \\
\text { resources }\end{array}$ & 0.57 & 0.49 & .22 & .05 & .11 & -.16 & $.43 \Phi$ & & \\
\hline 7 & $\begin{array}{l}\text { Prediction of human } \\
\text { resources }\end{array}$ & 0.57 & 0.49 & -.05 & -.02 & .04 & .05 & .14 & .19 & \\
\hline 8 & $\begin{array}{l}\text { Prediction of finance } \\
\text { sequencing }\end{array}$ & 0.30 & 0.46 & .16 & -.04 & .14 & -.13 & $.42 \mathbb{I}$ & $.57 \Phi$ & .10 \\
\hline 9 & $\begin{array}{l}\text { Prediction of social } \\
\text { capital sequencing }\end{array}$ & 0.57 & 0.49 & .08 & .04 & .11 & -.02 & .21 & .19 & -.16 \\
\hline 10 & $\begin{array}{l}\text { Prediction of human } \\
\text { capital sequencing }\end{array}$ & 0.46 & 0.50 & .14 & -.08 & -.03 & -.13 & $.28 *$ & $.44 \mathbb{I}$ & .15 \\
\hline 11 & Moscow dummy & 0.39 & 0.49 & -.02 & .14 & -.01 & -.02 & .00 & -.04 & -.04 \\
\hline 12 & Ekaterinburg dummy & 0.31 & 0.46 & .14 & $-.33 \Phi$ & .01 & -.09 & .15 & .05 & .05 \\
\hline 13 & Petrozavodsk dummy & 0.28 & 0.45 & -.12 & .19 & .00 & .12 & -.15 & -.01 & -.01 \\
\hline 14 & Banking dummy & 0.27 & 0.44 & .01 & -.10 & -.09 & -.04 & -.17 & .01 & -.16 \\
\hline 15 & Trade dummy & 0.31 & 0.46 & .04 & -.03 & .01 & .17 & .22 & .19 & .04 \\
\hline 16 & $\begin{array}{l}\text { Manufacturing } \\
\text { dummy }\end{array}$ & 0.25 & 0.44 & .06 & .02 & .07 & .06 & .00 & -.17 & .06 \\
\hline 17 & $\begin{array}{l}\text { Resource sector } \\
\text { dummy }\end{array}$ & 0.15 & 0.36 & -.14 & .15 & .02 & $-.25^{*}$ & -.10 & -.05 & .04 \\
\hline 18 & Small firm dummy & 0.28 & 0.45 & .19 & -.09 & .20 & .05 & -.18 & -.06 & -.14 \\
\hline 19 & Medium firm dummy & 0.37 & 0.48 & -.15 & -.04 & $-.48 \mathrm{I}$ & -.11 & .07 & -.10 & .11 \\
\hline 20 & Large firm dummy & 0.33 & 0.47 & -.02 & .13 & $.30^{*}$ & .06 & .11 & .17 & .02 \\
\hline 21 & New venture dummy & 0.62 & 0.48 & -.10 & .11 & .10 & .04 & .07 & .12 & -.09 \\
\hline 22 & $\begin{array}{l}\text { Privatised firm } \\
\text { dummy }\end{array}$ & 0.38 & 0.48 & .10 & -.11 & -.10 & -.04 & -.07 & -.12 & .09 \\
\hline 23 & Firm age (year) & 9.32 & 11.12 & .06 & -.09 & .07 & .02 & .05 & .08 & .18 \\
\hline 24 & Revenue growth & 0.02 & 0.33 & .09 & .19 & $.33^{*}$ & -.01 & .26 & $.49 \mathrm{II}$ & .419 \\
\hline
\end{tabular}


TABLE 3

Means, Standard Deviations and Pearson's Correlations (Con't)

\begin{tabular}{|c|c|c|c|c|c|c|c|c|c|c|c|}
\hline & & 8 & 9 & 10 & 11 & 12 & 13 & 14 & 15 & 16 & 17 \\
\hline 9 & $\begin{array}{l}\text { Prediction of social } \\
\text { capital sequencing }\end{array}$ & .579 & & & & & & & & & \\
\hline 10 & $\begin{array}{l}\text { Prediction of human } \\
\text { capital sequencing }\end{array}$ & $.63 \pi$ & .22 & & & & & & & & \\
\hline 11 & Moscow dummy & $.26^{*}$ & $.32^{*}$ & .13 & & & & & & & \\
\hline 12 & Ekaterinburg dummy & .04 & -.09 & -.02 & $-.55 \Phi$ & & & & & & \\
\hline 13 & Petrozavodsk dummy & $-.33^{*}$ & -.25 & -.11 & $-.51 \Phi$ & $-.43 \Phi$ & & & & & \\
\hline 14 & Banking dummy & -.06 & -.16 & .05 & -.01 & .16 & -.16 & & & & \\
\hline 15 & Trade dummy & .23 & $.26^{*}$ & $.27 *$ & -.01 & .02 & -.01 & $-.41 \Phi$ & & & \\
\hline 16 & $\begin{array}{l}\text { Manufacturing } \\
\text { dummy }\end{array}$ & -.16 & -.09 & -.19 & .02 & -.03 & .01 & $-.36 \mathbb{I}$ & $-.40 \mathbb{I}$ & & \\
\hline 17 & $\begin{array}{l}\text { Resource sector } \\
\text { dummy }\end{array}$ & -.04 & -.05 & -.07 & .01 & -.19 & .19 & $-.25 \mathbb{I}$ & $-.28 \mathrm{II}$ & $-.24^{*}$ & \\
\hline 18 & Small firm dummy & -.06 & .24 & -.13 & -.03 & .14 & -.11 & -.16 & $.28 *$ & .08 & $-.26^{*}$ \\
\hline 19 & Medium firm dummy & -.16 & -.25 & -.02 & -.18 & .07 & .12 & .01 & -.06 & .04 & .01 \\
\hline 20 & Large firm dummy & .24 & .02 & .16 & .21 & -.20 & -.02 & .14 & -.20 & -.12 & .23 \\
\hline 21 & New venture dummy & $.33^{*}$ & .19 & .379 & .18 & -.01 & -.19 & .05 & .19 & $-.24 *$ & -.01 \\
\hline 22 & $\begin{array}{l}\text { Privatised firm } \\
\text { dummy }\end{array}$ & -.33 & -.19 & $-.37 \Phi$ & -.18 & .01 & .19 & -.05 & -.19 & $.25^{*}$ & .01 \\
\hline 23 & Firm age (year) & -.21 & $-.31 *$ & -.20 & -.21 & .06 & .17 & -.18 & $-.26^{*}$ & $.41 \Phi$ & .06 \\
\hline 24 & Revenue growth & .45 II & .08 & $.32 *$ & -.12 & .23 & -.09 & -.11 & -.01 & .05 & .05 \\
\hline
\end{tabular}


TABLE 3

Means, Standard Deviations and Pearson's Correlations (Con't)

\begin{tabular}{|c|c|c|c|c|c|c|c|}
\hline & & 18 & 19 & 20 & 21 & 22 & 23 \\
\hline 19 & Medium firm dummy & $-.49 \mathrm{II}$ & & & & & \\
\hline 20 & Large firm dummy & $-.45 \mathrm{II}$ & $-.55 \mathbb{I}$ & & & & \\
\hline 21 & New venture dummy & .01 & .09 & -.11 & & & \\
\hline 22 & $\begin{array}{l}\text { Privatised firm } \\
\text { dummy }\end{array}$ & -.01 & -.01 & .11 & -1.00 & & \\
\hline 23 & Firm age & $-.26^{*}$ & $-.26^{*}$ & $.33 \mathbb{I}$ & $-.69 \mathrm{II}$ & 69I & \\
\hline 24 & Revenue growth & .09 & -.16 & .07 & .21 & -.21 & -.04 \\
\hline
\end{tabular}


TABLE 4

Regression Analysis Predicting Average Revenue Growth (N=56)

\begin{tabular}{|c|c|c|c|c|c|c|}
\hline & Model 1 & Model 2 & Model 3 & Model 4 & Model 5 & Model 6 \\
\hline \multicolumn{7}{|l|}{ Region dummies } \\
\hline Moscow & $\begin{array}{l}-0.04 \\
(0.12)\end{array}$ & $\begin{array}{l}-0.00 \\
(0.12)\end{array}$ & $\begin{array}{l}-0.00 \\
(0.12)\end{array}$ & $\begin{array}{l}-0.04 \\
(0.10)\end{array}$ & $\begin{array}{l}0.13 \\
(0.12)\end{array}$ & $\begin{array}{l}0.00 \\
(0.11)\end{array}$ \\
\hline Ekaterinburg & $\begin{array}{l}0.17 \\
(0.13)\end{array}$ & $\begin{array}{l}0.26 \\
(0.14)\end{array}$ & $\begin{array}{l}0.18 \\
(0.14)\end{array}$ & $\begin{array}{l}0.10 \\
(0.11)\end{array}$ & $\begin{array}{l}0.02 \\
(0.13)\end{array}$ & $\begin{array}{l}0.13 \\
(0.12)\end{array}$ \\
\hline \multicolumn{7}{|l|}{ Industry dummies } \\
\hline Banking & $\begin{array}{l}-0.19 \\
(0.18)\end{array}$ & $\begin{array}{l}-0.18 \\
(0.18)\end{array}$ & $\begin{array}{l}-0.21 \\
(0.18)\end{array}$ & $\begin{array}{l}-0.21 \\
(0.14)\end{array}$ & $\begin{array}{l}-0.17 \\
(0.17)\end{array}$ & $\begin{array}{l}-0.21 \\
(0.15)\end{array}$ \\
\hline Trade & $\begin{array}{l}-0.14 \\
(0.16)\end{array}$ & $\begin{array}{l}-0.14 \\
(0.15)\end{array}$ & $\begin{array}{l}-0.13 \\
(0.17)\end{array}$ & $\begin{array}{l}-0.21 \\
(0.13)\end{array}$ & $\begin{array}{l}-0.17 \\
(0.14)\end{array}$ & $\begin{array}{l}-0.16 \\
(0.14)\end{array}$ \\
\hline Manufacturing & $\begin{array}{l}-0.05 \\
(0.17)\end{array}$ & $\begin{array}{l}-0.09 \\
(0.17)\end{array}$ & $\begin{array}{l}-0.06 \\
(0.17)\end{array}$ & $\begin{array}{l}-0.00 \\
(0.14)\end{array}$ & $\begin{array}{l}-0.02 \\
(0.15)\end{array}$ & $\begin{array}{l}-0.03 \\
(0.13)\end{array}$ \\
\hline \multicolumn{7}{|l|}{ Firm size dummies } \\
\hline Small firms & $\begin{array}{l}0.11 \\
(0.11)\end{array}$ & $\begin{array}{l}0.13 \\
(0.17)\end{array}$ & $\begin{array}{l}0.00 \\
(0.14)\end{array}$ & $\begin{array}{l}0.16 \\
(0.10)\end{array}$ & $\begin{array}{l}0.16 \\
(0.10)\end{array}$ & $\begin{array}{l}0.05 \\
(0.11)\end{array}$ \\
\hline Large firms & $\begin{array}{l}0.14 \\
(0.12)\end{array}$ & $\begin{array}{l}0.12 \\
(0.12)\end{array}$ & $\begin{array}{l}0.02 \\
(0.15)\end{array}$ & $\begin{array}{l}0.17 \\
(0.10)\end{array}$ & $\begin{array}{l}0.03 \\
(0.12)\end{array}$ & $\begin{array}{l}-0.08 \\
(0.13)\end{array}$ \\
\hline New venture dummy & $\begin{array}{l}0.20 \\
(0.14)\end{array}$ & $\begin{array}{l}0.21 \\
(0.14)\end{array}$ & $\begin{array}{l}0.13 \\
(0.15)\end{array}$ & $\begin{array}{l}0.05 \\
(0.12)\end{array}$ & $\begin{array}{l}0.10 \\
(0.14)\end{array}$ & $\begin{array}{l}-0.05 \\
(0.13)\end{array}$ \\
\hline Firm age & $\begin{array}{l}0.01 \\
(0.01)\end{array}$ & $\begin{array}{l}0.00 \\
(0.00)\end{array}$ & $\begin{array}{l}0.00 \\
(0.00)\end{array}$ & $\begin{array}{l}-0.00 \\
(0.00)\end{array}$ & $\begin{array}{l}0.00 \\
(0.00)\end{array}$ & $\begin{array}{l}-0.00 \\
(0.00)\end{array}$ \\
\hline \multicolumn{7}{|l|}{ Independent variables } \\
\hline Network size & & $\begin{array}{l}-0.00 \\
(0.00)\end{array}$ & & & & $\begin{array}{l}0.00 \\
(0.00)\end{array}$ \\
\hline Network heterophily & & $\begin{array}{l}0.68 \\
(0.35)\end{array}$ & & & & $\begin{array}{l}0.74 * \\
(0.29)\end{array}$ \\
\hline Industry experience & & & $\begin{array}{l}0.18 \\
(0.12)\end{array}$ & & & $\begin{array}{l}0.23^{*} \\
(0.10)\end{array}$ \\
\hline Managerial experience & & & $\begin{array}{l}0.00 \\
(0.10)\end{array}$ & & & $\begin{array}{l}-0.02 \\
(0.09)\end{array}$ \\
\hline Prediction of financial resources & & & & $\begin{array}{l}0.04 \\
(0.09)\end{array}$ & & $\begin{array}{l}-0.01 \\
(0.09)\end{array}$ \\
\hline Prediction of social resources & & & & $\begin{array}{l}0.28 \mathbb{I} \\
(0.09)\end{array}$ & & $\begin{array}{l}0.16 \\
(0.10)\end{array}$ \\
\hline Prediction of human resources & & & & $\begin{array}{l}0.25 \mathrm{I} \\
(0.07)\end{array}$ & & $\begin{array}{l}0.20^{*} \\
(0.07)\end{array}$ \\
\hline Prediction of finance sequencing & & & & & $\begin{array}{l}0.46 \text { I } \\
(0.16)\end{array}$ & $\begin{array}{l}0.30 \\
(0.15)\end{array}$ \\
\hline Prediction of social capital sequencing & & & & & $\begin{array}{l}-0.17 \\
(0.12)\end{array}$ & $\begin{array}{l}-0.14 \\
(0.10)\end{array}$ \\
\hline Prediction of human capital sequencing & & & & & $\begin{array}{l}0.00 \\
(0.12)\end{array}$ & $\begin{array}{l}0.02 \\
(0.11)\end{array}$ \\
\hline Model $F$ & 1.02 & 1.20 & 1.04 & 3.44प & $2.08^{*}$ & 3.34 II \\
\hline$R$ square & 0.18 & 0.24 & 0.22 & 0.51 & 0.39 & 0.66 \\
\hline
\end{tabular}

Values represent unstandartized coefficients; standard errors are in parentheses.

$*=p<0.05$ in two $=$ tailed tests. $\mathrm{II}=\mathrm{p}<0.01$ in two=tailed tests. $\dagger=\mathrm{p}<0.001$ in two=tailed tests. 


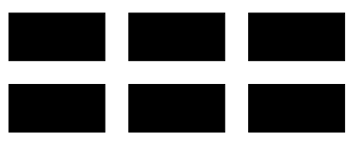

THE WILLIAM DAVIDSON INSTITUTE

AT THE UNIVERSITY OF MICHIGAN BUSINESSSCHOOL

\section{DAVIDSON INSTITUTE WORKING PAPER SERIES}

Working Papers are available at: www.wdi.bus.umich.edu

CURRENT AS OF $12 / 20 / 00$

\begin{tabular}{|c|c|c|}
\hline Publication & Authors & Date \\
\hline $\begin{array}{l}\text { No. 351 Entrepreneurial Versatility, Resources and Firm Performance in } \\
\text { Russia: A Panel Study }\end{array}$ & Bat Batjargal & Dec. 2000 \\
\hline $\begin{array}{l}\text { No. } 350 \text { The Dynamics of Entrepreneurial Networks in a Transitional } \\
\text { Economy: The Case of Russia }\end{array}$ & Bat Batjargal & Dec. 2000 \\
\hline $\begin{array}{l}\text { No. } 349 \text { R\&D and Technology Spillovers via FDI: Innovation and } \\
\text { Absorptive Capacity }\end{array}$ & Yuko Kinoshita & Nov. 2000 \\
\hline $\begin{array}{l}\text { No. } 348 \text { Microeconomic aspects of Economic Growth in Eastern } \\
\text { Europe and the Former Soviet Union, } 1950-2000\end{array}$ & Sergei Guriev and Barry W. Ickes & Nov. 2000 \\
\hline $\begin{array}{l}\text { No. } 347 \text { Effective versus Statutory Taxation: Measuring Effective Tax } \\
\text { Administration in Transition Economies }\end{array}$ & $\begin{array}{l}\text { Mark E. Schaffer and Gerard } \\
\text { Turley }\end{array}$ & Nov. 2000 \\
\hline $\begin{array}{l}\text { No. } 346 \text { Objectives and Constraints of Entrepreneurs: Evidence from } \\
\text { Small and Medium Size Enterprises in Russia and Bulgaria }\end{array}$ & $\begin{array}{l}\text { Francesca Pissarides, Miroslav } \\
\text { Singer and Jan Svejnar }\end{array}$ & Oct. 2000 \\
\hline No. 345 Corruption and Anticorruption in the Czech Republic & $\begin{array}{l}\text { Lubomír Lízal and Evžen } \\
\text { Kočenda }\end{array}$ & Oct. 2000 \\
\hline No. 344 The Effects of Direct Foreign Investment on Domestic Firms & Jozef Konings & Oct. 2000 \\
\hline No. 343 On the Identification of Relative Wage Rigidity Dynamics & uhani & Oct. 2000 \\
\hline $\begin{array}{l}\text { No. } 342 \text { The Determinants of Foreign Direct Investment in Transition } \\
\text { Economies }\end{array}$ & Alan A. Bevan and Saul Estrin & Oct. 2000 \\
\hline No. 341 The Global Spread of Stock Exchanges, 1980-1998 & Klaus Weber an & Nov. 2000 \\
\hline $\begin{array}{l}\text { No. } 340 \text { The Costs and Benefits of Euro-isation in Central-Eastern } \\
\text { Europe Before or Instead of EMU Membership }\end{array}$ & D. Mario Nuti & Oct. 2000 \\
\hline No. 339 Debt Overhang and Barter in Russia & $\begin{array}{l}\text { Sergei Guriev, Igor Makarov and } \\
\text { Mathilde Maurel }\end{array}$ & Sept. 2000 \\
\hline $\begin{array}{l}\text { No. } 338 \text { Firm Performance and the Political Economy of Corporate } \\
\text { Governance: Survey Evidence for Bulgaria, Hungary, Slovakia and } \\
\text { Slovenia }\end{array}$ & $\begin{array}{l}\text { Patrick Paul Walsh and Ciara } \\
\text { Whela }\end{array}$ & July 2000 \\
\hline No. 337 Investment and Instability & $\begin{array}{l}\text { Nauro F. Campos a } \\
\text { Nugent }\end{array}$ & May 2000 \\
\hline $\begin{array}{l}\text { No. } 336 \text { The Evolution of the Insurance Sector in Central and } \\
\text { Eastern Europe and the former Soviet Union }\end{array}$ & Robert B.K. Pye & Aug. 2000 \\
\hline $\begin{array}{l}\text { No. } 335 \text { Institutional Technology and the Chains of Trust: Capital } \\
\text { Markets and Privatization in Russia and the Czech Republic }\end{array}$ & Bruce Kogut and Andrew Spicer & Aug. 2000 \\
\hline No. 334 The Evolution of Market Integration in Russia & $\begin{array}{l}\text { Daniel Berkowitz and David N. } \\
\text { DeJong }\end{array}$ & Aug. 2000 \\
\hline No. 333 Efficiency and Market Share in Hungarian Corporate Sector & László Halpern and Gábor Körösi & July 2000 \\
\hline No. 332 Search-Money-and-Barter Models of Financial Stabilization & $\begin{array}{l}\text { S.I. Boyarchenko and S.Z. } \\
\text { Levendorskii }\end{array}$ & July 2000 \\
\hline $\begin{array}{l}\text { No. } 331 \text { Worker Training in a Restructuring Economy: Evidence from } \\
\text { the Russian Transition }\end{array}$ & $\begin{array}{l}\text { Mark C. Berger, John S. Earle } \\
\text { and Klara Z. Sabirianova }\end{array}$ & Aug. 2000 \\
\hline $\begin{array}{l}\text { No. } 330 \text { Economic Development in Palanpur 1957-1993: A Sort of } \\
\text { Growth }\end{array}$ & Peter Lanjouw & Aug. 2000 \\
\hline $\begin{array}{l}\text { No. } 329 \text { Trust, Organizational Controls, Knowledge Acquisition from } \\
\text { the Foreign Parents, and Performance in Vietnamese International Joint } \\
\text { Ventures }\end{array}$ & $\begin{array}{l}\text { Marjorie A. Lyles, Le Dang } \\
\text { Doanh, and Jeffrey Q. Barden }\end{array}$ & June 2000 \\
\hline $\begin{array}{l}\text { No. } 328 \text { Comparative Advertising in the Global Marketplace: The } \\
\text { Effects of Cultural Orientation on Communication }\end{array}$ & $\begin{array}{l}\text { Zeynep Gürhan-Canli and } \\
\text { Durairaj Maheswaran }\end{array}$ & Aug. 2000 \\
\hline No. 327 Post Privatization Enterprise Restructuring & Morris Bornstein & July 2000 \\
\hline
\end{tabular}




\begin{tabular}{|c|c|c|}
\hline No. 326 Who is Afraid of Political Instability? & $\begin{array}{l}\text { Nauro F. Campos and Jeffrey B. } \\
\text { Nugent }\end{array}$ & July 2000 \\
\hline No. 325 Business Groups, the Financial Market and Modernization & Raja Kali & June 2000 \\
\hline $\begin{array}{l}\text { No. } 324 \text { Restructuring with What Success? A Case Study of Russian } \\
\text { Firms }\end{array}$ & Susan Linz & July 2000 \\
\hline $\begin{array}{l}\text { No. } 323 \text { Priorities and Sequencing in Privatization: Theory and } \\
\text { Evidence from the Czech Republic }\end{array}$ & $\begin{array}{l}\text { Nandini Gupta, John C. Ham and } \\
\text { Jan Svejnar }\end{array}$ & May 2000 \\
\hline $\begin{array}{l}\text { No. } 322 \text { Liquidity, Volatility, and Equity Trading Costs Across } \\
\text { Countries and Over Time }\end{array}$ & $\begin{array}{l}\text { Ian Domowitz, Jack Glen and } \\
\text { Ananth Madhavan }\end{array}$ & Mar. 2000 \\
\hline $\begin{array}{l}\text { No. } 321 \text { Equilibrium Wage Arrears: A Theoretical and Empirical } \\
\text { Analysis of Institutional Lock-In }\end{array}$ & $\begin{array}{l}\text { John S. Earle and Klara Z. } \\
\text { Sabirianova }\end{array}$ & Oct. 2000 \\
\hline No. 320 Rethinking Marketing Programs for Emerging Markets & $\begin{array}{l}\text { Niraj Dawar and Amitava } \\
\text { Chattopadhyay }\end{array}$ & June 2000 \\
\hline $\begin{array}{l}\text { No. } 319 \text { Public Finance and Low Equilibria in Transition Economies: } \\
\text { the Role of Institutions }\end{array}$ & $\begin{array}{l}\text { Daniel Daianu and Radu } \\
\text { Vranceanu }\end{array}$ & June 2000 \\
\hline $\begin{array}{l}\text { No. } 318 \text { Some Econometric Evidence on the Effectiveness of Active } \\
\text { Labour Market Programmes in East Germany }\end{array}$ & $\begin{array}{l}\text { Martin Eichler and Michael } \\
\text { Lechner }\end{array}$ & June 2000 \\
\hline No. 317 A Model of Russia's "Virtual Economy" & R.E Ericson and B.W Ickes & May 2000 \\
\hline $\begin{array}{l}\text { No. } 316 \text { Financial Institutions, Financial Contagion, and Financial } \\
\text { Crises }\end{array}$ & $\begin{array}{l}\text { Haizhou Huang and Chenggang } \\
\mathrm{Xu}\end{array}$ & Mar. 2000 \\
\hline $\begin{array}{l}\text { No. } 315 \text { Privatization versus Regulation in Developing Economies: The } \\
\text { Case of West African Banks }\end{array}$ & $\begin{array}{l}\text { Jean Paul Azam, Bruno Biais, and } \\
\text { Magueye Dia }\end{array}$ & Feb. 2000 \\
\hline $\begin{array}{l}\text { No. } 314 \text { Is Life More Risky in the Open? Household Risk-Coping and } \\
\text { the Opening of China's Labor Markets }\end{array}$ & John Giles & Apr. 2000 \\
\hline $\begin{array}{l}\text { No. } 313 \text { Networks, Migration and Investment: Insiders and Outsiders in } \\
\text { Tirupur's Production Cluster }\end{array}$ & $\begin{array}{l}\text { Abhijit Banerjee and Kaivan } \\
\text { Munshi }\end{array}$ & Mar. 2000 \\
\hline $\begin{array}{l}\text { No. } 312 \text { Computational Analysis of the Impact on India of the Uruguay } \\
\text { Round and the Forthcoming WTO Trade Negotiations }\end{array}$ & $\begin{array}{l}\text { Rajesh Chadha, Drusilla K. } \\
\text { Brown, Alan V. Deardorff and } \\
\text { Robert M. Stern }\end{array}$ & Mar. 2000 \\
\hline No. 311 Subsi & Jan. C. van Ours & May 2000 \\
\hline No. 310 Determinants of Managerial Pay in the Czech Republic & $\begin{array}{l}\text { Tor Eriksson, } \\
\text { and Pavel Mr: }\end{array}$ & May 2000 \\
\hline $\begin{array}{l}\text { No. } 309 \text { The Great Human Capital Reallocation: An Empirical Analysis } \\
\text { of Occupational Mobility in Transitional Russia }\end{array}$ & Klara Z. Sabirianova & Oct. 2000 \\
\hline No. 308 Economic Development, Legality, and the Transplant Effect & $\begin{array}{l}\text { Daniel Berkowitz, } \mathrm{K} \\
\text { Pistor, and Jean-Fra }\end{array}$ & Feb. 2000 \\
\hline $\begin{array}{l}\text { No. } 307 \text { Community Participation, Teacher Effort, and Educational } \\
\text { Outcome: The Case of El Salvador's EDUCO Program }\end{array}$ & Yasuyuki Sawada & Nov. 1999 \\
\hline No. 306 Gender Wage Gap and Segregation in Late Transition & Stepan Jurajda & May 2000 \\
\hline $\begin{array}{l}\text { No. } 305 \text { The Gender Pay Gap in the Transition from Communism: } \\
\text { Some Empirical Evidence }\end{array}$ & Andrew Newell and Barry Reilly & May 2000 \\
\hline No. 304 Post-Unification Wage Growth in East Germany & Jennifer Hunt & Nov. 1998 \\
\hline $\begin{array}{l}\text { No. } 303 \text { How Does Privatization Affect Workers? The Case of the } \\
\text { Russian Mass Privatization Program }\end{array}$ & Elizabeth Brainerd & May 2000 \\
\hline $\begin{array}{l}\text { No. } 302 \text { Liability for Past Environmental Contamination and } \\
\text { Privatization }\end{array}$ & Dietrich Earnhart & Mar. 2000 \\
\hline No. 301 Varieties, Jobs and EU Enlargement & $\begin{array}{l}\text { Tito Boeri and Joaquim Oliveira } \\
\text { Martins }\end{array}$ & May 2000 \\
\hline No. 300 Employer Size Eff & Todd Idson & Apr. 2000 \\
\hline $\begin{array}{l}\text { No. } 299 \text { Information Complements, Substitutes, and Strategic Product } \\
\text { Design }\end{array}$ & $\begin{array}{l}\text { Geoffrey G. Parker and Marshall } \\
\text { W. Van Alstyne }\end{array}$ & Mar. 2000 \\
\hline $\begin{array}{l}\text { No. } 298 \text { Markets, Human Capital, and Inequality: Evidence from Rural } \\
\text { China }\end{array}$ & $\begin{array}{l}\text { Dwayne Benjamin, Loren Brandt, } \\
\text { Paul Glewwe, and Li Guo }\end{array}$ & May 2000 \\
\hline No. 297 Corporate Governance in the Asian Financial Crisis & $\begin{array}{l}\text { Simon Johnson, Peter Boone, } \\
\text { Alasdair Breach, and Eric } \\
\text { Friedman }\end{array}$ & Nov. 1999 \\
\hline
\end{tabular}




\begin{tabular}{|c|c|c|}
\hline No. 296 Competition and Firm Performance: Lessons from Russia & J. David Brown and John S. Earle & Mar. 2000 \\
\hline No. 295 Wage Determination in Russia: An Econometric Investigation & $\begin{array}{l}\text { Peter J. Luke and Mark E. } \\
\text { Schaffer }\end{array}$ & Mar. 2000 \\
\hline $\begin{array}{l}\text { No. 294: Can Banks Promote Enterprise Restructuring?: Evidence From } \\
\text { a Polish Bank's Experience }\end{array}$ & John P. Bonin and Bozena Leven & Mar. 2000 \\
\hline No. 293: Why do Governments Sell Privatised Companies Abroad? & $\begin{array}{l}\text { Bernardo Bortolotti, Marcella } \\
\text { Fantini and Carlo Scarpa }\end{array}$ & Mar. 2000 \\
\hline $\begin{array}{l}\text { No. 292: Going Public in Poland: Case-by-Case Privatizations, Mass } \\
\text { Privatization and Private Sector Initial Public Offerings }\end{array}$ & Wolfgang Aussenegg & Dec. 1999 \\
\hline $\begin{array}{l}\text { No. 291: Institutional Technology and the Chains of Trust: Capital } \\
\text { Markets and Privatization in Russia and the Czech Republic }\end{array}$ & Bruce Kogut and Andrew Spicer & Mar. 1999 \\
\hline No. 290: Banking Crises and Bank Rescues: The Effect of Reputation & Jenny Corbett and Janet Mitchell & Jan. 2000 \\
\hline $\begin{array}{l}\text { No. 289: Do Active Labor Market Policies Help Unemployed Workers } \\
\text { to Find and Keep Regular Jobs? }\end{array}$ & Jan C. van Ours & Feb. 2000 \\
\hline No. 288: Consumption Patterns of the New Elite in Zimbabwe & Russell Belk & Feb. 2000 \\
\hline $\begin{array}{l}\text { No. 287: Barter in Transition Economies: Competing Explanations } \\
\text { Confront Ukranian Data }\end{array}$ & $\begin{array}{l}\text { Dalia Marin, Daniel Kaufmann } \\
\text { and Bogdan Gorochowskij }\end{array}$ & Jan. 2000 \\
\hline $\begin{array}{l}\text { No. 286: The Quest for Pension Reform: Poland's Security through } \\
\text { Diversity }\end{array}$ & $\begin{array}{l}\text { Marek Góra and Michael } \\
\text { Rutkowski }\end{array}$ & Jan. 2000 \\
\hline No. 285: Disorganization and Financial Collapse & $\begin{array}{l}\text { Dalia Marin and Monika } \\
\text { Schnitzer }\end{array}$ & Oct. 1999 \\
\hline No. 284: Coordinating Changes in M-form and U-form Organizations & $\begin{array}{l}\text { Yingyi Qian, Gérard Roland and } \\
\text { Chenggang Xu }\end{array}$ & May 1999 \\
\hline $\begin{array}{l}\text { No. 283: Why Russian Workers Do Not Move: Attachment of Workers } \\
\text { Through In-Kind Payments }\end{array}$ & Guido Friebel and Sergei Guriev & Oct. 1999 \\
\hline No. 282: Lessons From Fiascos in Russian Corporate Governance & $\begin{array}{l}\text { Merritt B. Fox and Michael A. } \\
\text { Heller }\end{array}$ & ct. 1999 \\
\hline $\begin{array}{l}\text { No. 281: Income Distribution and Price Controls: Targeting a Social } \\
\text { Safety Net During Economic Transition }\end{array}$ & $\begin{array}{l}\text { Michael Alexeev and James } \\
\text { Leitzel }\end{array}$ & 999 \\
\hline $\begin{array}{l}\text { No. 280: Starting Positions, Reform Speed, and Economic Outcomes in } \\
\text { Transitioning Economies }\end{array}$ & William Hallagan and Zhang Jun & Jan. 2000 \\
\hline No. 279: The Value of Prominent Directors & $\begin{array}{l}\text { Yoshiro Miwa \& J. Mark } \\
\text { Ramseyer }\end{array}$ & Oct. 1999 \\
\hline No. 278: The Syste & János Kornai & Apr. 1998 \\
\hline $\begin{array}{l}\text { No. 277: The Developmental Consequences of Foreign Direct } \\
\text { Investment in the Transition from Socialism to Capitalism: The } \\
\text { Performance of Foreign Owned Firms in Hungary }\end{array}$ & Lawrence Peter King & Sept. 1999 \\
\hline $\begin{array}{l}\text { No. 276: Stability and Disorder: An Evolutionary Analysis of Russia's } \\
\text { Virtual Economy }\end{array}$ & $\begin{array}{l}\text { Clifford Gaddy and Barry W. } \\
\text { Ickes }\end{array}$ & Nov. 1999 \\
\hline $\begin{array}{l}\text { No. 275: Limiting Government Predation Through Anonymous } \\
\text { Banking: A Theory with Evidence from China. }\end{array}$ & $\begin{array}{l}\text { Chong-En Bai, David D. Li, } \\
\text { Yingyi Qian and Yijiang Wang }\end{array}$ & July 1999 \\
\hline No. 274: Transition with Labour Supply & Tito Boeri & Dec. 1999 \\
\hline $\begin{array}{l}\text { No. 273: Sectoral Restructuring and Labor Mobility: A Comparative } \\
\text { Look at the Czech Republic }\end{array}$ & Vit Sorm and Katherine Terrell & Nov. 1999 \\
\hline $\begin{array}{l}\text { No. 272: Published in: Journal of Comparative Economics "Returns to } \\
\text { Human Capital Under the Communist Wage Grid and During the } \\
\text { Transition to a Market Economy" Vol. 27, pp. 33-60 } 1999 .\end{array}$ & $\begin{array}{l}\text { Daniel Munich, Jan Svejnar and } \\
\text { Katherine Terrell }\end{array}$ & Oct. 1999 \\
\hline $\begin{array}{l}\text { No. 271: Barter in Russia: Liquidity Shortage Versus Lack of } \\
\text { Restructuring }\end{array}$ & $\begin{array}{l}\text { Sophie Brana and Mathilde } \\
\text { Maurel }\end{array}$ & June 1999 \\
\hline $\begin{array}{l}\text { No. 270: Tests for Efficient Financial Intermediation with Application to } \\
\text { China }\end{array}$ & Albert Park and Kaja Sehrt & Mar. 1999 \\
\hline $\begin{array}{l}\text { No. 269a: Russian Privatization and Corporate Governance: What Went } \\
\text { Wrong? }\end{array}$ & $\begin{array}{l}\text { Bernard Black, Reinier Kraakman } \\
\text { and Anna Tarassova }\end{array}$ & May 2000 \\
\hline $\begin{array}{l}\text { No. 269: Russian Privatization and Corporate Governance: What Went } \\
\text { Wrong? }\end{array}$ & $\begin{array}{l}\text { Bernard Black, Reinier Kraakman } \\
\text { and Anna Tarassova }\end{array}$ & Sept. 1999 \\
\hline No. 268: Are Russians Really Ready for Capitalism? & Susan Linz & Sept. 1999 \\
\hline
\end{tabular}


Davidson Institute Working Papers are available at: www.wdi.bus.umich.edu

\begin{tabular}{|c|c|c|}
\hline No. 267: Do Stock Markets Promote Economic Growth? & $\begin{array}{l}\text { Randall K. Filer, Jan Hanousek } \\
\text { and Nauro Campos }\end{array}$ & Sept. 1999 \\
\hline $\begin{array}{l}\text { No. 266: Objectivity, Proximity and Adaptability in Corporate } \\
\text { Governance }\end{array}$ & $\begin{array}{l}\text { Arnoud W.A Boot and Jonathan } \\
\text { R. Macey }\end{array}$ & Sept. 1999 \\
\hline $\begin{array}{l}\text { No. 265: When the Future is not What it Used to Be: Lessons from the } \\
\text { Western European Experience to Forecasting Education and Training in } \\
\text { Transitional Economies }\end{array}$ & $\begin{array}{l}\text { Nauro F. Campos, Gerard } \\
\text { Hughes, Stepan Jurajda, and } \\
\text { Daniel Munich }\end{array}$ & Sept. 1999 \\
\hline $\begin{array}{l}\text { No. 264: The Institutional Foundation of Foreign-Invested Enterprises } \\
\text { (FIEs) in China }\end{array}$ & Yasheng Huang & Sept. 1999 \\
\hline $\begin{array}{l}\text { No. 263: The Changing Corporate Governance Paradigm: Implications } \\
\text { for Transition and Developing Countries }\end{array}$ & $\begin{array}{l}\text { Erik Berglof and Ernst-Ludwig } \\
\text { von Thadden }\end{array}$ & 1999 \\
\hline No. 262: Law Enforcement and Transition & $\begin{array}{l}\text { Gerard Roland and Thierry } \\
\text { Verdier }\end{array}$ & 1999 \\
\hline $\begin{array}{l}\text { No. 261: Soft Budget Constraints, Pecuniary Externality, and the Dual } \\
\text { Track System }\end{array}$ & Jiahua Che & 2000 \\
\hline $\begin{array}{l}\text { No. 260: Missing Market in Labor Quality: The Role of Quality Markets } \\
\text { in Transition }\end{array}$ & G & 1999 \\
\hline $\begin{array}{l}\text { No. 259: Do Corporate Global Environmental Standards in Emerging } \\
\text { Markets Create or Destroy Market Value }\end{array}$ & $\begin{array}{l}\text { Glen Dowell, Stuart } \\
\text { Bernard Yeung }\end{array}$ & June 1999 \\
\hline No. 258: Public Training and Outflows from Unemployment & Patrick A. Puhani & June 1999 \\
\hline $\begin{array}{l}\text { No. 257: Ownership Versus Environment: Why are Public Sector } \\
\text { Inefficient? }\end{array}$ & n & June 1999 \\
\hline $\begin{array}{l}\text { No. 256: Taxation and Evasion in the Presence of Exortion by } \\
\text { Organized Crime }\end{array}$ & 1 1 lover Eclhor & 1999 \\
\hline No. 255: Revisiting Hungary’s Bankruptcy Episode & $\begin{array}{ll}\text { Bonir } \\
\mathrm{r}\end{array}$ & Sept. 1999 \\
\hline No. 254: FDI & V.N W & 1999 \\
\hline $\begin{array}{l}\text { No. 253: The Asian Financial Crisis: What Happened } \\
\text { Done }\end{array}$ & 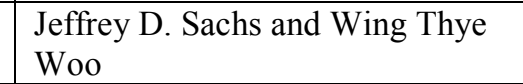 & Jan. 1999 \\
\hline No. 252: Organizational Law as Asset Partitioning & $\begin{array}{l}\text { Hansm } \\
\operatorname{man}\end{array}$ & 1999 \\
\hline $\begin{array}{l}\text { No. } 25 \\
\text { the Cas }\end{array}$ & ip & 9 \\
\hline Organization of Exchange & $\begin{array}{ll}\text { ren } \\
\text { lle }\end{array}$ & July 1998 \\
\hline $\begin{array}{l}\text { No. 249: Impacts of the Indonesian Economic Crisis: Price Changes and } \\
\text { the Poor }\end{array}$ & $\begin{array}{l}\text { Jam } \\
\text { and }\end{array}$ & 99 \\
\hline $\begin{array}{l}\text { No. 248: Internal Barriers in the Transition of Enterprises from Central } \\
\text { Plan to Market }\end{array}$ & Charalambos Vlachoutsicos & July 1999 \\
\hline $\begin{array}{l}\text { No. 247: Spillovers from Multinationals in Developing Countries: the } \\
\text { Mechanisms at Work }\end{array}$ & E. Caves & 1999 \\
\hline $\begin{array}{l}\text { No. 246: Dynamism and Inertia on the Russian Labour Market: A } \\
\text { Model of Segmentation }\end{array}$ & $\begin{array}{l}\text { Irena Grosfeld, Claudia Senik- } \\
\text { Leygonie, Thierry Verdier, Stanislav } \\
\text { Kolenikov and Elena Paltseva }\end{array}$ & 999 \\
\hline No. 245: I & John Bonin and Paul Wachtel & 1999 \\
\hline $\begin{array}{l}\text { No. 244: Nominal-Real Tradeoffs and the Effects of Monetary Policy: } \\
\text { the Romanian Experience }\end{array}$ & Christian Popa & Dec. 1998 \\
\hline $\begin{array}{l}\text { No. 243: Privatization, Political Risk and Stock Market Development in } \\
\text { Emerging Economies }\end{array}$ & $\begin{array}{l}\text { Enrico C. Perot } \\
\text { Oijen }\end{array}$ & Mar. 1999 \\
\hline No. 242: Investment Financing in Russian Financial-Industrial Groups & $\begin{array}{l}\text { Enrico C. Perotti and Stanislav } \\
\text { Gelfer }\end{array}$ & Oct. 1998 \\
\hline $\begin{array}{l}\text { No. 241: Can governments } \\
\text { lending and financial isolati }\end{array}$ & $\begin{array}{l}\text { Octavian Carare, Constantijn } \\
\text { Claessens, Enrico C. Perotti }\end{array}$ & Jan. 1999 \\
\hline $\begin{array}{l}\text { No. 240: Democratic Institutions and Economic Reform: the Polish } \\
\text { Case }\end{array}$ & $\begin{array}{l}\text { John E. Jackson, Jacek Klich, and } \\
\text { Krystyna Poznanska }\end{array}$ & Apr. 1998 \\
\hline
\end{tabular}




\begin{tabular}{|c|c|c|}
\hline No. 239: A Longitudinal Study of IJV Performance in Eastern Europe & $\begin{array}{l}\text { Keith D. Brouthers and Gary } \\
\text { Bamossy }\end{array}$ & June 1999 \\
\hline $\begin{array}{l}\text { No. 238: Published in: Journal of Business Venturing, "Firm Creation } \\
\text { and Economic Transitions" } 14(5,6) \text { Sep/Nov 1999, pp. 427-450. }\end{array}$ & $\begin{array}{l}\text { John E. Jackson, Jacek Klich, } \\
\text { Krystyna Poznanska }\end{array}$ & July 1998 \\
\hline No. 237: Analysis of Entrepreneurial Attitudes in Poland & $\begin{array}{l}\text { John E. Jackson and Aleksander } \\
\text { S. Marcinkowski }\end{array}$ & Mar. 1997 \\
\hline $\begin{array}{l}\text { No. 236: Investment and Finance in De Novo Private Firms: Empirical } \\
\text { Results from the Czech Republic, Hungary, and Poland }\end{array}$ & $\begin{array}{l}\text { Andrzej Bratkowski, Irena } \\
\text { Grosfeld, Jacek Rostowski }\end{array}$ & Apr. 1999 \\
\hline $\begin{array}{l}\text { No. 235: Does a Soft Macroeconomic Environment Induce } \\
\text { Restructuring on the Microeconomic Level during the Transition } \\
\text { Period? Evidence from Investment Behavior of Czech Enterprises }\end{array}$ & Lubomír Lízal & June 1999 \\
\hline $\begin{array}{l}\text { No. 234: Banking Reform in China: Gradually Strengthening Pillar or } \\
\text { Fragile Reed? }\end{array}$ & John Bonin & June 1999 \\
\hline $\begin{array}{l}\text { No. 233: Theories of Soft Budget Constraints and the Analysis of } \\
\text { Banking Crises }\end{array}$ & Janet Mitchell & Mar. 1999 \\
\hline $\begin{array}{l}\text { No. 232: Unemployment Risk, Precautionary Savings, and } \\
\text { Moonlighting in Russia }\end{array}$ & $\begin{array}{l}\text { Alessandra Guariglia and Byung- } \\
\text { Yeon Kim }\end{array}$ & June 1999 \\
\hline $\begin{array}{l}\text { No. 231: Investing in Turbulent Times: The Investment Behavior of } \\
\text { Polish Firms in the Transition }\end{array}$ & $\begin{array}{l}\text { Josef C. Brada, Arthur E. King, } \\
\text { and Chia-Ying Ma }\end{array}$ & Apr. 1999 \\
\hline No. 230: The End of Moderate Inflation in Three Transition Economies? & Josef C. Brada and Ali M. Kutan & Apr. 1999 \\
\hline $\begin{array}{l}\text { No. 229: Back to the Future: The Growth Prospects of Transition } \\
\text { Economies Reconsidered }\end{array}$ & Nauro F. Campos & Apr. 1999 \\
\hline No. 228: The Enterprise Isolation Program in Russia & Simeon Djankov & Apr. 1999 \\
\hline $\begin{array}{l}\text { No. 227: Published in: Journal of Comparative Economics, "Ownership } \\
\text { Concentration and Corporate Performance in the Czech Republic" } \\
\text { 27(3), Sept. 1999, pp. 498-513. }\end{array}$ & $\begin{array}{l}\text { Stijn Claessens and Simeon } \\
\text { Djankov }\end{array}$ & Apr. 1999 \\
\hline $\begin{array}{l}\text { No. 226: Published in Journal of Population Economics, "Poland on the } \\
\text { Dole: The Effect of Reducing the Unemployment Benefit Entitlement } \\
\text { Period during Transition" 13:35-44, } 2000 \text {. }\end{array}$ & Patrick A. Puhani & Mar. 1999 \\
\hline No. 225: Transition at Whirlpool-Tatramat: Case Studies & $\begin{array}{l}\text { Hans Brechbuhl and Sonia } \\
\text { Ferencikova }\end{array}$ & Mar. 1999 \\
\hline $\begin{array}{l}\text { No. 224: Measuring Progress in Transition and Towards EU Accession: } \\
\text { A Comparison of Manufacturing Firms in Poland, Romania, and Spain }\end{array}$ & $\begin{array}{l}\text { Wendy Carlin, Saul Estrin, and } \\
\text { Mark Schaffer }\end{array}$ & Mar. 1999 \\
\hline $\begin{array}{l}\text { No. 223: Product Market Competition in Transition Economies: } \\
\text { Increasing Varieties and Consumer Loyalty }\end{array}$ & Mitsutoshi M. Adachi & Mar. 1999 \\
\hline $\begin{array}{l}\text { No. 222: Opaque Markets and Rapid Growth: the Superiority of Bank- } \\
\text { Centered Financial Systems for Developing Nations }\end{array}$ & Rodney Wallace & July 1999 \\
\hline No. 221: Technology Spillovers through Foreign Direct Investment & Yuko Kinoshita & Jan. 1999 \\
\hline $\begin{array}{l}\text { No. 220: Managerial, Expertise and Team Centered Forms of } \\
\text { Organizing: A Cross-Cultural Exploration of Independence in } \\
\text { Engineering Work }\end{array}$ & Leslie Perlow & Jan. 1999 \\
\hline $\begin{array}{l}\text { No. 219: Household Structure and Labor Demand in Agriculture: } \\
\text { Testing for Separability in Rural China }\end{array}$ & $\begin{array}{l}\text { Audra J. Bowlus and Terry } \\
\text { Sicular }\end{array}$ & Jan. 1999 \\
\hline $\begin{array}{l}\text { No. 218: Competing Strategies of FDI and Technology Transfer to } \\
\text { China: American and Japanese Firms }\end{array}$ & $\begin{array}{l}\text { W. Mark Fruin and Penelope } \\
\text { Prime }\end{array}$ & Jan. 1999 \\
\hline $\begin{array}{l}\text { No. } 217 \text { Published in: Journal of Comparative Economics, "Returns to } \\
\text { Mobility in the Transition to a Market Economy" 27(1), Mar } 1999 .\end{array}$ & $\begin{array}{l}\text { Tito Boeri and Christopher J. } \\
\text { Flinn }\end{array}$ & Jan. 1999 \\
\hline $\begin{array}{l}\text { No. } 216 \text { Published in: Journal of Comparative Economics, "Labor } \\
\text { Market Policies and Unemployment in the Czech Republic." 27(1), Mar } \\
\text { 1999, pp. 33-60. }\end{array}$ & Katherine Terrell and Vit Sorm & Nov. 1998 \\
\hline $\begin{array}{l}\text { No. } 215 \text { Published in: Journal of Comparative Economics, “Active } \\
\text { Labor Market Policies in Poland: Human Capital Enhancement, } \\
\text { Stigmatization or Benefit Churning?" 27(1), Mar 1999, pp. 61-. }\end{array}$ & $\begin{array}{l}\text { Jochen Kluve, Hartmut Lehmann, } \\
\text { and Christoph M. Schmidt }\end{array}$ & Dec. 1998 \\
\hline $\begin{array}{l}\text { No. } 214 \text { Published in: Journal of Comparative Economics, "Does the } \\
\text { Slovenian Public Work Program Increase Participants' Chances to Find } \\
\text { a Job?" 27(1), Mar 1999, pp. 113- . }\end{array}$ & lopivec & Dec. 1998 \\
\hline
\end{tabular}




\begin{tabular}{|c|c|c|}
\hline $\begin{array}{l}\text { No. } 213 \text { Published in: Journal of Comparative Economics, "Effects of } \\
\text { Active Labor Market Programs on the Transition Rate from } \\
\text { Unemployment into Regular Jobs in the Slovak Republic." 27(1), Mar } \\
\text { 1999, pp. 90- . }\end{array}$ & $\begin{array}{l}\text { Martina Lubyova and Jan C. van } \\
\text { Ours }\end{array}$ & Dec. 1998 \\
\hline $\begin{array}{l}\text { No. 212: The Marketing System in Bulgarian Livestock Production - } \\
\text { The Present State and Evolutionary Processes During the Period of } \\
\text { Economic Transition }\end{array}$ & Yordan Staykov, Team Leader & Oct. 1998 \\
\hline No. 211: Bankruptcy Experience in Hungary and the Czech Republic & Janet Mitchell & Oct. 1998 \\
\hline $\begin{array}{l}\text { No 210: Values, Optimum Stimulation Levels and Brand Loyalty: New } \\
\text { Scales in New Populations }\end{array}$ & $\begin{array}{l}\text { Steven M. Burgess and Mari } \\
\text { Harris }\end{array}$ & Sept. 1998 \\
\hline No. 209: Inherited Wealth, Corporate Control and Economic Growth & $\begin{array}{l}\text { Randall K. Morck, David A. } \\
\text { Stangeland, and Bernard Yeung }\end{array}$ & Sept. 1998 \\
\hline $\begin{array}{l}\text { No. 208: A Cultural Analysis of Homosocial Reproduction and } \\
\text { Contesting Claims to Competence in Transitional Firms }\end{array}$ & Michael D. Kennedy & July 1998 \\
\hline $\begin{array}{l}\text { No. 207: From Survival to Success: The Journey of Corporate } \\
\text { Transformation at Haier. Forthcoming in Managing Organizational } \\
\text { Change in Transition Economies ed. Daniel Denison. }\end{array}$ & $\begin{array}{l}\text { Arthur Yeung and Kenneth } \\
\text { DeWoskin }\end{array}$ & July 1998 \\
\hline $\begin{array}{l}\text { No. 206: Why Do People Work If They Are Not Paid? An Example } \\
\text { from Eastern Europe. Forthcoming in Managing Organizational Change } \\
\text { in Transition Economies. }\end{array}$ & Irina L. Zinovieva & May 1998 \\
\hline $\begin{array}{l}\text { No. 205: Firm Ownership and Work Motivation in Bulgaria and } \\
\text { Hungary: An Empirical Study of the Transition in the Mid-1990s. } \\
\text { Forthcoming in Managing Organizational Change in Transition } \\
\text { Economies ed. Daniel Denison. }\end{array}$ & $\begin{array}{l}\text { Robert A. Roe, Irina L. } \\
\text { Zinovieva, Elizabeth Dienes, and } \\
\text { Laurens A. ten Horn }\end{array}$ & May 1998 \\
\hline $\begin{array}{l}\text { No. 204: Human Resource Management in the Restructuring of Chinese } \\
\text { Joint Ventures. Forthcoming in Managing Organizational Change in } \\
\text { Transition Economies ed. Daniel Denison. }\end{array}$ & Nandani Lynton & Apr. 1998 \\
\hline $\begin{array}{l}\text { No. 203: Emergent Compensation Strategies in Post-Socialist Poland: } \\
\text { Understanding the Cognitive Underpinnings of Management Practices } \\
\text { in a Transition Economy. Forthcoming in Managing Organizational } \\
\text { Change in Transition Economies ed. Daniel Denison. }\end{array}$ & Marc Weinstein & Mar. 1998 \\
\hline $\begin{array}{l}\text { No. 202: Corporate Transformation and Organizational Learning: The } \\
\text { People's Republic of China. Forthcoming in Managing Organizational } \\
\text { Change in Transition Economies ed. Daniel Denison. }\end{array}$ & $\begin{array}{l}\text { Meinolf Dierkes and Zhang } \\
\text { Xinhua }\end{array}$ & Mar. 1998 \\
\hline $\begin{array}{l}\text { No. 201: Foreign Direct Investment as a Factor of Change: The Case of } \\
\text { Slovakia. Forthcoming in Managing Organizational Change in } \\
\text { Transition Economies ed. Daniel Denison. }\end{array}$ & Sonia Ferencikova & Feb. 1998 \\
\hline $\begin{array}{l}\text { No. 200: Radical versus Incremental Change: The Role of Capabilities, } \\
\text { Competition, and Leaders. Forthcoming in Managing Organizational } \\
\text { Change in Transition Economies ed. Daniel Denison. }\end{array}$ & Karen L. Newman & Feb. 1998 \\
\hline $\begin{array}{l}\text { No. 199: The Emergence of Market Practices in China's Economic } \\
\text { Transition: Price Setting Practices in Shanghai's Industrial Firms. } \\
\text { Forthcoming in Managing Organizational Change in Transition } \\
\text { Economies ed. Daniel Denison. }\end{array}$ & Douglas Guthrie & Feb. 1998 \\
\hline $\begin{array}{l}\text { No. 198: The Application of Change Management Methods at Business } \\
\text { Organizations Operating in Hungary: Challenges in the Business and } \\
\text { Cultural Environment and First Practical Experiences. Forthcoming in } \\
\text { Managing Organizational Change in Transition Economies ed. Daniel } \\
\text { Denison. }\end{array}$ & Dr. János Fehér & Jan. 1998 \\
\hline $\begin{array}{l}\text { No. 197: Organizational Changes in Russian Industrial Enterprises: } \\
\text { Mutation of Decision-Making Structures and Transformations of } \\
\text { Ownership. Forthcoming in Managing Organizational Change in } \\
\text { Transition Economies ed. Daniel Denison. }\end{array}$ & Igor B. Gurkov & Jan. 1998 \\
\hline $\begin{array}{l}\text { No. 196: Understanding and Managing Challenges to the Romanian } \\
\text { Companies during Transition. Forthcoming in Managing Organizational } \\
\text { Change in Transition Economies ed. Daniel Denison. }\end{array}$ & $\begin{array}{l}\text { Dan Cander } \\
\text { Candea }\end{array}$ & 998 \\
\hline
\end{tabular}




\begin{tabular}{|c|c|c|}
\hline $\begin{array}{l}\text { No. 195: Insider Lending and Economic Transition: The Structure, } \\
\text { Function, and Performance Impact of Finance Companies in Chinese } \\
\text { Business Groups. Forthcoming in Managing Organizational Change in } \\
\text { Transition Economies ed. Daniel Denison. }\end{array}$ & Lisa A. Keister & Dec. 1997 \\
\hline $\begin{array}{l}\text { No. 194: Japanese Investment in Transitional Economies: } \\
\text { Characteristics and Performance. Forthcoming in Managing } \\
\text { Organizational Change in Transition Economies ed. Daniel Denison. }\end{array}$ & $\begin{array}{l}\text { Paul W. Beamish and Andrew } \\
\text { Delios }\end{array}$ & Nov. 1997 \\
\hline $\begin{array}{l}\text { No. 193: Building Successful Companies in Transition Economies. } \\
\text { Forthcoming in Managing Organizational Change in Transition } \\
\text { Economies ed. Daniel Denison. }\end{array}$ & Dr. Ivan Perlaki & Jan. 1998 \\
\hline $\begin{array}{l}\text { No. 192: Russian Communitariansim: An Invisible Fist in the } \\
\text { Transformation Process of Russia. Forthcoming in Managing } \\
\text { Organizational Change in Transition Economies ed. Daniel Denison. }\end{array}$ & Charalambos Vlachoutsicos & July 1998 \\
\hline No. 191: Teaching the Dinosaurs to Dance & Michal Cakrt & Sept. 1997 \\
\hline $\begin{array}{l}\text { No. 190: Strategic Restructuring: Making Capitalism in Post- } \\
\text { Communist Eastern Europe. Forthcoming in Managing Organizational } \\
\text { Change in Transition Economies ed. Daniel Denison. }\end{array}$ & Lawrence P. King & Sept. 1997 \\
\hline $\begin{array}{l}\text { No. 189: Published in: Regional Science and Urban Economics, } \\
\text { "Russia's Internal Border." 29(5), Sept. } 1999 .\end{array}$ & $\begin{array}{l}\text { Daniel Berkowitz and David N. } \\
\text { DeJong }\end{array}$ & July 1998 \\
\hline No. 187: Corporate Structure and Performance in Hungary & László Halpern and Gábor Kórsöi & July 1998 \\
\hline No. 186: Performance of Czech Companies by Ownership Structure & $\begin{array}{l}\text { Andrew Weiss and Georgiy } \\
\text { Nikitin }\end{array}$ & June 1998 \\
\hline $\begin{array}{l}\text { No. 185: Firm Performance in Bulgaria and Esto } \\
\text { competitive pressure, financial pressure and diso }\end{array}$ & Jozef Konings & July 1998 \\
\hline $\begin{array}{l}\text { No. 184: Investment and Wages during the Transition: Evidence from } \\
\text { Slovene Firms }\end{array}$ & Janez Prasnikar and Jan Svejnar & July 1998 \\
\hline $\begin{array}{l}\text { No. 183: Investment Portfolio under Soft Budget: Implications for } \\
\text { Growth, Volatility and Savings }\end{array}$ & Chongen Bai and Yijiang Wang & July 1998 \\
\hline No. 181: Delegation and Delay in Bank Privatization & $\begin{array}{l}\text { Loránd Ambrus-Lakat } \\
\text { Ulrich Hege }\end{array}$ & July 1998 \\
\hline No. 180: Financing Mechanisms and R\&D Investment & $\begin{array}{l}\text { Haizhou Huang and Chenggang } \\
\mathrm{Xu}\end{array}$ & July 1998 \\
\hline $\begin{array}{l}\text { No. 179: Organizational Culture and Effectiveness: The Case of Foreign } \\
\text { Firms in Russia }\end{array}$ & $\begin{array}{l}\text { Carl F. Fey and Daniel R. } \\
\text { Denison }\end{array}$ & Jan. 1999 \\
\hline No. 178: Output and Unemployment Dynamics in Transition & $\begin{array}{l}\text { Vivek H. Dehejia and Douglas W. } \\
\text { Dwyer }\end{array}$ & Jan. 1998 \\
\hline $\begin{array}{l}\text { No. 177: Published in: Economics of Transition, "Bureaucracies in the } \\
\text { Russian Voucher Privatization." } 8(1), 2000, \text { pp. } 37-57 .\end{array}$ & Guido Friebel & June 1998 \\
\hline No. 176: Chronic Moderate Inflation in Transition: The Tale of Hungary & János Vincze & June 1998 \\
\hline No. 175: Privatisation and Market Structure in a Transition Economy & John Bennett and James Maw & June 1998 \\
\hline $\begin{array}{l}\text { No. 174: Ownership and Managerial Competition: Employee, Customer, } \\
\text { or Outside Ownership }\end{array}$ & $\begin{array}{l}\text { Patrick Bolton and Chenggang } \\
\mathrm{Xu}\end{array}$ & June 1998 \\
\hline $\begin{array}{l}\text { No. 173: Intragovernment Procurement of Local Public Good: A } \\
\text { Theory of Decentralization in Nondemocratic Government }\end{array}$ & $\begin{array}{l}\text { Chong-en Bai, Yu Pan and } \\
\text { Yijiang Wang }\end{array}$ & June 1998 \\
\hline No. 172: Political Instability and Growth in Proprietary Economies & $\begin{array}{l}\text { Jody Overland and Michael } \\
\text { Spagat }\end{array}$ & Aug. 1998 \\
\hline $\begin{array}{l}\text { No. 171: Published in Post-Communist Economies, "Framework Issues } \\
\text { in the Privatization Strategies of the Czech Republic, Hungary, and } \\
\text { Poland" 11(1) Mar. 1999. }\end{array}$ & Morris Bornstein & June 1998 \\
\hline $\begin{array}{l}\text { No. 170: Published in: European Journal of Political Economy } \\
\text { "Privatization, Ownership Structure and Transparency: How to Measure } \\
\text { a Real Involvement of the State" 15(4), Nov. 1999, pp. 605-18. }\end{array}$ & Frantisek Turnovec & May 1998 \\
\hline $\begin{array}{l}\text { No. } 169 \text { Published in: American Economic Review, "Unemployment and } \\
\text { the Social Safety Net during Transitions to a Market Economy: } \\
\text { Evidence from Czech and Slovak Men" 88(5), Dec 1998, pp. 1117-1142 }\end{array}$ & $\begin{array}{l}\text { John C. Ham, Jan Svejnar, and } \\
\text { Katherine Terrell }\end{array}$ & Dec. 1998 \\
\hline
\end{tabular}




\begin{tabular}{|c|c|c|}
\hline $\begin{array}{l}\text { No. 167: Voucher Privatization with Investment Funds: An Institutional } \\
\text { Analysis }\end{array}$ & David Ellerman & Mar. 1998 \\
\hline $\begin{array}{l}\text { No. 166: Published in: Marketing Issues in Transitional Economies, } \\
\text { "Value Priorities and Consumer Behavior in a Transitional Economy: } \\
\text { The Case of South Africa" ed. Rajeev Batra. }\end{array}$ & $\begin{array}{l}\text { Steven M. Burgess and Jan- } \\
\text { Benedict E.M. Steenkamp }\end{array}$ & Aug. 1998 \\
\hline $\begin{array}{l}\text { No. 164: Finance and Investment in Transition: Czech Enterprises, } \\
\text { 1993-1994 }\end{array}$ & $\begin{array}{l}\text { Ronald Anderson and Chantal } \\
\text { Kegels }\end{array}$ & Sept. 1997 \\
\hline $\begin{array}{l}\text { No. 163: European Union Trade and Investment Flows U-Shaping } \\
\text { Industrial Output in Central and Eastern Europe: Theory and Evidence }\end{array}$ & $\begin{array}{l}\text { Alexander Repkine and Patrick P. } \\
\text { Walsh }\end{array}$ & Apr. 1998 \\
\hline $\begin{array}{l}\text { No. 162: Skill Acquisition and Private Firm Creation in Transition } \\
\text { Economies }\end{array}$ & Zuzana Brixiova and Wenli Li & Oct. 1999 \\
\hline No. 161: Corruption in Transition & Susanto Basu and David D. Li & May 1998 \\
\hline $\begin{array}{l}\text { No. 160a: Tenures that Shook the World: Worker Turnover in Russia, } \\
\text { Poland and Britain }\end{array}$ & $\begin{array}{l}\text { Hartmut Lehmann and Jonathan } \\
\text { Wadsworth }\end{array}$ & Nov. 1999 \\
\hline $\begin{array}{l}\text { No. 160: Tenures that Shook the World: Worker Turnover in the } \\
\text { Russian Federation and Poland }\end{array}$ & $\begin{array}{l}\text { Hartmut Lehmann and Jonathan } \\
\text { Wadsworth }\end{array}$ & June 1998 \\
\hline No. 159: Does Market Structure Matter? New Evidence from Russia & $\begin{array}{l}\text { Annette N. Brown and J. David } \\
\text { Brown }\end{array}$ & June 1998 \\
\hline $\begin{array}{l}\text { No. 158: Structural Adjustment and Regional Long Term } \\
\text { Unemployment in Poland }\end{array}$ & $\begin{array}{l}\text { Hartmut Lehmann and Patrick P. } \\
\text { Walsh }\end{array}$ & June 1997 \\
\hline $\begin{array}{l}\text { No. 157: Baby Boom or Bust? Changing Fertility in Post-Communist } \\
\text { Czech Republic and Slovakia }\end{array}$ & Robert S. Chase & Apr. 1998 \\
\hline $\begin{array}{l}\text { No. } 156 \text { Published in: Leadership and Organization Development } \\
\text { Journal, "Leading Radical Change in Transition Economies." Vol. 19, } \\
\text { No. 6, 1998, pp. 309-324. }\end{array}$ & Karen L. Newman & June 1998 \\
\hline $\begin{array}{l}\text { No. } 155 \text { Published in: Oxford Review of Economic Policy, "From } \\
\text { Theory into Practice? Restructuring and Dynamism in Transition } \\
\text { Economies." Vol. 13, No. 2, Summer 1997, pp. 77-105. }\end{array}$ & $\begin{array}{l}\text { Wendy Carlin and Michael } \\
\text { Landesmann }\end{array}$ & June 1997 \\
\hline $\begin{array}{l}\text { No. 154: The Model and the Reality: Assessment of Vietnamese SOE } \\
\text { Reform-Implementation at the Firm Level }\end{array}$ & $\begin{array}{l}\text { Edmund Malesky, Vu Thanh } \\
\text { Hung, Vu Thi Dieu Anh, and } \\
\text { Nancy K. Napier }\end{array}$ & July 1998 \\
\hline $\begin{array}{l}\text { No. } 153 \text { Published in: Journal of Comparative Economics, "Causes of } \\
\text { the Soft Budget Constraint: Evidence on Three Explanations." Vol. 26, } \\
\text { No. 1, Mar. 1998, pp. 104-116. }\end{array}$ & David D. Li and Minsong Liang & Mar. 1998 \\
\hline $\begin{array}{l}\text { No. } 152 \text { Published in: Comparative Economic Studies, "Enterprise } \\
\text { Restructuring in Russia's Transition Economy: Formal and Informal } \\
\text { Mechanisms." Vol. 40, No. 2, Summer 1998, pp. 5-52. }\end{array}$ & Susan J. Linz & Apr. 1998 \\
\hline $\begin{array}{l}\text { No. 151: Labor Productivity in Transition: A Regional Analysis of } \\
\text { Russian Industry }\end{array}$ & Susan J. Linz & May 1998 \\
\hline $\begin{array}{l}\text { No. 150: Tax Avoidance and the Allocation of Credit. Forthcoming in } \\
\text { Financial Systems in Transition: The Design of Financial Systems in } \\
\text { Central Europe eds. Anna Meyendorff and Anjan Thakor. }\end{array}$ & Anna Meyendorff & June 1998 \\
\hline $\begin{array}{l}\text { No. 149: Commitment, Versatility and Balance: Determinants of Work } \\
\text { Time Standards and Norms in a Multi-Country Study of Software } \\
\text { Engineers }\end{array}$ & Leslie Perlow and Ron Fortgang & Apr. 1998 \\
\hline $\begin{array}{l}\text { No. 148: Changes in Poland's Transfer Payments in the 1990s: the Fate } \\
\text { of Pensioners }\end{array}$ & Bozena Leven & June 1998 \\
\hline $\begin{array}{l}\text { No. 147: Environmental Protection and Economic Development: The } \\
\text { Case of the Huaihe River Basin Cleanup Plan }\end{array}$ & $\begin{array}{l}\text { Robert Letovsky, Reze Ramazani, } \\
\text { and Debra Murphy }\end{array}$ & June 1998 \\
\hline $\begin{array}{l}\text { No. 146: Chief Executive Compensation During Early Transition: } \\
\text { Further Evidence from Bulgaria }\end{array}$ & $\begin{array}{l}\text { Derek C. Jones, Takao Kato, and } \\
\text { Jeffrey Miller }\end{array}$ & June 1998 \\
\hline $\begin{array}{l}\text { No. } 145 \text { Published in: Economics of Transition, "Women's } \\
\text { Unemployment During the Transition: Evidence from Czech and Slovak } \\
\text { Micro Data," Vol. 7, No. 1, May 1999, pp. 47-78. }\end{array}$ & $\begin{array}{l}\text { John Ham, Jan Svejnar, and } \\
\text { Katherine Terrell }\end{array}$ & May 1998 \\
\hline No. 144: Investment and Wages in Slovenia & Janez Prasnikar & May 1998 \\
\hline
\end{tabular}


Davidson Institute Working Papers are available at: www.wdi.bus.umich.edu

\begin{tabular}{|c|c|c|}
\hline $\begin{array}{l}\text { No. } 143 \text { Published in: Review of Financial Studies, "Optimal } \\
\text { Bankruptcy Laws Across Different Economic Systems," 12(2), 47-77, } \\
\text { Summer } 19993 .\end{array}$ & $\begin{array}{l}\text { Elazar Berkovitch and Ronen } \\
\text { Israel }\end{array}$ & Mar. 1998 \\
\hline $\begin{array}{l}\text { No. 142: Industrial Policy and Poverty in Transition Economies: Two } \\
\text { Steps Forward or One Step Back? }\end{array}$ & Susan J. Linz & Mar. 1998 \\
\hline $\begin{array}{l}\text { No. } 141 \text { Collective Ownership and Privatization of China's Village } \\
\text { Enterprises }\end{array}$ & Suwen Pan and Albert Park & Apr. 1998 \\
\hline $\begin{array}{l}\text { No. } 140 \text { A Comparative Look at Labor Mobility in the Czech Republic: } \\
\text { Where have all the Workers Gone? }\end{array}$ & Vit Sorm and Katherine Terrell & Apr. 1999 \\
\hline $\begin{array}{l}\text { No. } 139 \text { The Failure of the Government-Led Program of Corporate } \\
\text { Reorganization in Romania }\end{array}$ & $\begin{array}{l}\text { Simeon Djankov and Kosali } \\
\text { Ilayperuma }\end{array}$ & Sept. 1997 \\
\hline No. 138 Ownership and Employment in Russian Industry: 1992-1995 & Susan J. Linz & Mar. 1998 \\
\hline $\begin{array}{l}\text { No. } 137 \text { Published in: Journal of Political Economy, "Reform Without } \\
\text { Losers: An Interpretation of China's Dual-Track Approach to } \\
\text { Transition," Feb. 2000; Vol. 108, Iss.1; pg. } 120\end{array}$ & $\begin{array}{l}\text { Lawrence J. Lau, Yingyi Qian, } \\
\text { and Gerard Roland }\end{array}$ & Nov. 1997 \\
\hline $\begin{array}{l}\text { No. } 136 \text { Published in: European Economic Review, "The Political } \\
\text { Economy of Mass Privatization and the Risk of Expropriation," 44(2), } \\
\text { Feb. 2000, pgs. 393-421 }\end{array}$ & Klaus M. Schmidt & Mar. 1998 \\
\hline $\begin{array}{l}\text { No. 135: Radical Organizational Change: The Role of Starting } \\
\text { Conditions, Competition, and Leaders }\end{array}$ & Karen L. Newman & Jan. 1998 \\
\hline $\begin{array}{l}\text { No. 134: To Restructure or Not to Restructure: Informal Activities and } \\
\text { Enterprise Behavior in Transition }\end{array}$ & $\begin{array}{l}\text { Clifford Gaddy and Barry W. } \\
\text { Ickes }\end{array}$ & May 1998 \\
\hline No. 133: Management 101: Behavior of Firms in Transition Economies & Josef C. Brada & Mar. 1998 \\
\hline $\begin{array}{l}\text { No. } 132 \text { Published in: Quarterly Journal of Economics, "Interfirm } \\
\text { Relationships and Informal Credit in Vietnam," 114(4), Nov. 1999, pgs. } \\
1285-1320\end{array}$ & $\begin{array}{l}\text { John McMillan and Christopher } \\
\text { Woodruff }\end{array}$ & Feb. 1998 \\
\hline $\begin{array}{l}\text { No. } 131 \text { Published in: Comparative Economic Studies, "Will } \\
\text { Restructuring Hungarian Companies Innovate? An Investigation Based } \\
\text { on Joseph Berliner's Analysis of Innovation in Soviet Industry." Vol. } \\
\text { 40, No. 2, Summer 1998, pp. 53-74. }\end{array}$ & John B. B & 1998 \\
\hline $\begin{array}{l}\text { No. 130: Published in The American Economic Review, "Changing } \\
\text { Incentives of the Chinese Bureaucracy." May, 1998. }\end{array}$ & David D. Li & Jan. 1998 \\
\hline $\begin{array}{l}\text { No. 129: Restructuring Investment in Transition: A Model of the } \\
\text { Enterprise Decision }\end{array}$ & Richard E. Ericson & Jan. 1998 \\
\hline $\begin{array}{l}\text { No. } 128 \text { Published in: Comparative Economic Studies, "Job Rights in } \\
\text { Russian Firms: Endangered or Extinct Institutions?" Vol. 40, No. 4, } \\
\text { Winter 1998, pp. 1-32. }\end{array}$ & Susan J. Linz & Jan. 1998 \\
\hline No. 127: Accounting for Growth in Post-Soviet Russia & $\begin{array}{l}\text { Daniel Berkowitz and David N. } \\
\text { DeJong }\end{array}$ & Jan. 1998 \\
\hline $\begin{array}{l}\text { No. } 126 \text { Published in: Economics of Transition, "From Federalism, } \\
\text { Chinese Style, to Privatization Chinese Style," } 7(1), 1999 \text {, pgs. 103-31 }\end{array}$ & $\begin{array}{l}\text { Yuanzheng Cao, Yingyi Qian, } \\
\text { and Barry R. Weingast }\end{array}$ & Dec. 1997 \\
\hline $\begin{array}{l}\text { No. 125: Market Discipline in Conglomerate Banks: Is an Internal } \\
\text { Allocation of Cost of Capital Necessary as Incentive Device? } \\
\text { Forthcoming in Financial Systems in Transition: The Design of } \\
\text { Financial Systems in Central Europe eds. Anna Meyendorff and Anjan } \\
\text { Thakor. }\end{array}$ & $\begin{array}{l}\text { Arnoud W. A. Boot and Anjolein } \\
\text { Schmeits }\end{array}$ & Nov. 1997 \\
\hline $\begin{array}{l}\text { No. 124: Financial Discipline in the Enterprise Sector in Transition } \\
\text { Countries: How Does China Compare? }\end{array}$ & $\begin{array}{l}\text { Shumei Gao and Mark E. } \\
\text { Schaffer }\end{array}$ & Feb. 1998 \\
\hline $\begin{array}{l}\text { No. 123: Considerations of an Emerging Marketplace: Managers' } \\
\text { Perceptions in the Southern African Economic Community }\end{array}$ & Brent Chrite and David Hudson & Feb. 1998 \\
\hline No. 122: A Model of the Informal Economy in Transition Economies & $\begin{array}{l}\text { Simon Commander and Andrei } \\
\text { Tolstopiatenko }\end{array}$ & Nov. 1997 \\
\hline $\begin{array}{l}\text { No. 121: Local Labour Market Dynamics in the Czech and Slovak } \\
\text { Republics }\end{array}$ & $\begin{array}{l}\text { Peter Huber and Andreas } \\
\text { Worgotter }\end{array}$ & Nov. 1997 \\
\hline $\begin{array}{l}\text { No. 119: Published in Academy of Management Review, "Organizational } \\
\text { Transformation during Institutional Upheaval," } 25 \text { (3), 2000, p. 602-619 }\end{array}$ & Karen L. Newman & Mar. 1998 \\
\hline
\end{tabular}




\begin{tabular}{|c|c|c|}
\hline No. 118: Industrial Decline and Labor Reallocation in Romania & John S. Earle & Oct. 1997 \\
\hline No. 117: Notes for an Essay on the Soft Budget Constraint & Lorand Ambrus-Lakatos & Jan. 1997 \\
\hline No. 116: Labor Demand During Transition in Hungary & Gabor Korosi & Oct. 1997 \\
\hline No. 115: Enterprise Performance and Managers' Profiles & $\begin{array}{l}\text { Simeon Djankov and Stijn } \\
\text { Claessens }\end{array}$ & Dec. 1997 \\
\hline $\begin{array}{l}\text { No. 114b Employment and Wages in Enterprises under Communism } \\
\text { and in Transition: Evidence From Central Europe and Russia }\end{array}$ & $\begin{array}{l}\text { Swati Basu, Saul Estrin, and Jan } \\
\text { Svejnar }\end{array}$ & Apr. 2000 \\
\hline $\begin{array}{l}\text { No. 114: Employment and Wage Behavior of Enterprises in Transitional } \\
\text { Economies }\end{array}$ & $\begin{array}{l}\text { Swati Basu, Saul Estrin, and Jan } \\
\text { Svejnar }\end{array}$ & Oct. 1997 \\
\hline $\begin{array}{l}\text { No. 113: Preliminary Evidence on Active Labor Programs' Impact in } \\
\text { Hungary and Poland }\end{array}$ & Christopher J. O’Leary & Oct. 1997 \\
\hline $\begin{array}{l}\text { No. 111: Unemployment Benefits and Incentives in Hungary: New } \\
\text { Evidence }\end{array}$ & Joachim Wolff & Oct. 1997 \\
\hline $\begin{array}{l}\text { No. 110: Published in: Empirical Economics, "Long-Term } \\
\text { Unemployment, Unemployment Benefits and Social Assistance: The } \\
\text { Polish Experience" Empirical-Economics; 23(1-2), 1998, pp. 55-85. }\end{array}$ & $\begin{array}{l}\text { Marek Gora and Christoph M. } \\
\text { Schmidt }\end{array}$ & Apr. 1997 \\
\hline $\begin{array}{l}\text { No. } 109 \text { Published in: Industrial and Labor Relations Review, "Markets } \\
\text { for Communist Human Capital: Returns to Education and Experience in } \\
\text { Post-Communist Czech Republic and Slovakia." 51(3), Apr. 1998, pp. } \\
\text { 401-423. }\end{array}$ & Robert S. Chase & Oct. 1997 \\
\hline $\begin{array}{l}\text { No. 107: The Worker-Firm Matching in the Transition: (Why) Are the } \\
\text { Czechs More Successful Than Others? }\end{array}$ & $\begin{array}{l}\text { Daniel Münich, Jan Svejnar, and } \\
\text { Katherine Terrell }\end{array}$ & Oct. 1997 \\
\hline $\begin{array}{l}\text { No. } 106 \text { Published in: Journal of Comparative Economics, "Job } \\
\text { Creation, Job Destruction and Growth of Newly Established, Privatized } \\
\text { and State-Owned Enterprises in Transition Economies: Survey Evidence } \\
\text { from Bulgaria, Hungary, and Romania," 26(3), Sept. 1998, pp. 429-445. }\end{array}$ & $\begin{array}{l}\text { Valentijn Bilsen and Jozef } \\
\text { Konings }\end{array}$ & Sept. 1998 \\
\hline $\begin{array}{l}\text { No. 105: Getting Behind the East-West [German] Wage Differential: } \\
\text { Theory and Evidence }\end{array}$ & $\begin{array}{l}\text { Michael Burda and Christoph } \\
\text { Schmidt }\end{array}$ & May 1997 \\
\hline No. 104: The Birth of the "Wage Curve" in Hungary, 1989-95 & Gabor Kertesi and Janos Kollo & Oct. 1997 \\
\hline $\begin{array}{l}\text { No. 103: Published in: Journal of Comparative Economics, "Grime and } \\
\text { Punishment: Job Insecurity and Wage Arrears in the Russian } \\
\text { Federation" 27, 595-617 (1999). }\end{array}$ & $\begin{array}{l}\text { Hartmut Lehmann, Jonathan } \\
\text { Wadsworth, and Alessandro } \\
\text { Acquisti }\end{array}$ & Oct. 1997 \\
\hline No. 102: Social Networks in Transition & $\begin{array}{l}\text { Lorena Barberia, Simon Johnson, } \\
\text { and Daniel Kaufmann }\end{array}$ & Oct. 1997 \\
\hline $\begin{array}{l}\text { No. 101: Depreciation and Russian Corporate Finance: A Pragmatic } \\
\text { Approach to Surviving the Transition }\end{array}$ & Susan J. Linz & Nov. 1997 \\
\hline No. 100: Romanian Financial System Reform & $\begin{array}{l}\text { Anna Meyendorff and Anjan V. } \\
\text { Thakor }\end{array}$ & Nov. 1997 \\
\hline $\begin{array}{l}\text { No. 99: Proceedings of the Conference on Strategic Alliances in } \\
\text { Transitional Economies, held May 20,1997 at the Davidson Institute }\end{array}$ & Edited by Cynthia Koch & May 1997 \\
\hline No. 98: Institutions, Strain and the Underground Economy & Daniel Daianu and L & Nov. 1997 \\
\hline No. 97: Structure and Strain in Explair & Daniel Dai & Nov. 1997 \\
\hline $\begin{array}{l}\text { No. 96: Resource Misallocation and Strain: Explaining Shocks in Post- } \\
\text { Command Economies }\end{array}$ & Daniel Daianu & Nov. 1997 \\
\hline $\begin{array}{l}\text { No. 95: Published in: Finance-a-Uver, "Czech Money Market: Emerging } \\
\text { Links Among Interest Rates." 48(2) } 1998 \text { pp. 99-109. }\end{array}$ & $\begin{array}{l}\text { Jan Hanousek and Evzen } \\
\text { Kocenda }\end{array}$ & Nov. 1997 \\
\hline $\begin{array}{l}\text { No. 94: Pre-Reform Industry and the } \\
\text { State Monopsony in China }\end{array}$ & $\begin{array}{l}\text { Xiao-Yuan Dong and Louis } \\
\text { Putterman }\end{array}$ & Oct. 1997 \\
\hline $\begin{array}{l}\text { No. 93: China's State-Owned Enterprises } \\
\text { In the First Reform Decade: } \\
\text { An Analysis of a Declining Monopsony }\end{array}$ & $\begin{array}{l}\text { Xiao-Yuan Dong and Louis } \\
\text { Putterman }\end{array}$ & Oct. 1997 \\
\hline No. 92: Expatriate Management in the Czech Republic & Richard B. Peterson & Sept. 1997 \\
\hline No. 91: China and the Idea of Economic Reform & Thomas G. Rawski & Apr. 1997 \\
\hline $\begin{array}{l}\text { No. } 90 \text { Published in: China Economic Review, "China's State Enterpr } \\
\text { Reform: An Overseas Perspective.” Vol. 8, Spring 1997, pp. 89-98. }\end{array}$ & Thomas G. Rawski & July 1997 \\
\hline
\end{tabular}




\begin{tabular}{|c|c|c|}
\hline $\begin{array}{l}\text { No. 89: The Economic Determinants of Internal Migration Flows in } \\
\text { Russia During Transition }\end{array}$ & Annette N. Brown & July 1997 \\
\hline $\begin{array}{l}\text { No. 88: Gender Wage Gaps in China's Labor Market: Size, Structure, } \\
\text { Trends }\end{array}$ & $\begin{array}{l}\text { Margaret Maurer-Fazio, Thomas } \\
\text { G. Rawski, and Wei Zhang }\end{array}$ & July 1997 \\
\hline No. 87: Privatisation in Central and Eastern Europe & Saul Estrin & June 1997 \\
\hline $\begin{array}{l}\text { No. 86: Published in : Economics of Transition, "The Effect of } \\
\text { Privatization on Wealth Distribution in Russia." v. 7, no. 2, 1999, pp. } \\
449-65\end{array}$ & Michael Alexeev & Feb. 1998 \\
\hline $\begin{array}{l}\text { No. 85: Was Privatization in Eastern Germany a Special Case? Some } \\
\text { Lessons from the Treuhand }\end{array}$ & Uwe Siegmund & Sept. 1997 \\
\hline No. 84: Start-ups and Transition & $\begin{array}{l}\text { Daniel M. Berkowitz and David J. } \\
\text { Cooper }\end{array}$ & Sept. 1997 \\
\hline $\begin{array}{l}\text { No. 83: Which Enterprises (Believe They) Have Soft Budgets after } \\
\text { Mass Privatization? Evidence from Mongolia }\end{array}$ & $\begin{array}{l}\text { James Anderson, Georges } \\
\text { Korsun, and Peter Murrell }\end{array}$ & Oct. 1997 \\
\hline $\begin{array}{l}\text { No. 82: Published in: European Economic Review, "Unemployment } \\
\text { Dynamics and the Restructuring of the Slovak Unemployment Benefit } \\
\text { System." Apr., } 1997 .\end{array}$ & $\begin{array}{l}\text { Martina Lubyova and Jan C. van } \\
\text { Ours }\end{array}$ & June 1997 \\
\hline No. 81: Determinants of Unemployment Duration in Russia & Mark C. Foley & Aug. 1997 \\
\hline No. 80: The Many Faces of Information Disclosure & $\begin{array}{l}\text { Arnoud W.A. Boot and Anjan V. } \\
\text { Thakor }\end{array}$ & Oct. 1997 \\
\hline $\begin{array}{l}\text { No. 79: Published in: Journal of Finance, "Foreign Speculators and } \\
\text { Emerging Equity Markets."v.22, iss. 2, 2000, pp. 565-613 }\end{array}$ & $\begin{array}{l}\text { Geert Bekaert and Campbell R. } \\
\text { Harvey }\end{array}$ & Aug. 1997 \\
\hline $\begin{array}{l}\text { No. 78: The Relationship Between Economic Factors and Equity } \\
\text { Markets in Central Europe }\end{array}$ & $\begin{array}{l}\text { Jan Hanousek and Randall K. } \\
\text { Filer }\end{array}$ & June 1997 \\
\hline $\begin{array}{l}\text { No. } 77 \text { Published in: Economics of Transition, “A Gini Decomposition } \\
\text { Analysis of Inequality in the Czech and Slovak Republics During the } \\
\text { Transition," Vol. 6, No.1, May 1998, pp. 23-46. }\end{array}$ & $\begin{array}{l}\text { Thesia I. Garner and Katherine } \\
\text { Terrell }\end{array}$ & 1998 \\
\hline $\begin{array}{l}\text { No. 76: China's Emerging Market for Property Rights: Theoretical and } \\
\text { Empirical Perspectives }\end{array}$ & $\begin{array}{l}\text { Gary H. Jefferson and Thomas G. } \\
\text { Rawski }\end{array}$ & June 1997 \\
\hline $\begin{array}{l}\text { No. 75b: Test of Permanent Income Hypothesis on Czech Voucher } \\
\text { Privatization }\end{array}$ & Jan Hanousek and Zdenek Tima & Oct. 1997 \\
\hline $\begin{array}{l}\text { No. 74: Determinants of Performance of Manufacturing Firms in Seven } \\
\text { European Transition Economies }\end{array}$ & $\begin{array}{l}\text { Stijn Claessens, Simeon Djankov, } \\
\text { and Gerhard Pohl }\end{array}$ & Feb. 1997 \\
\hline $\begin{array}{l}\text { No. } 73 \text { Published in: Economics of Transition, "The Restructuring of } \\
\text { Large Firms in Slovak Republic." Vol. 6, No. 1, May 1998, pp. 67-85 }\end{array}$ & $\begin{array}{l}\text { Simeon Djankov and Gerhard } \\
\text { Pohl }\end{array}$ & May 1998 \\
\hline $\begin{array}{l}\text { No. 72: Law, Relationships, and Private Enforcement: Transactional } \\
\text { Strategies of Russian Enterprises }\end{array}$ & $\begin{array}{l}\text { Kathryn Hendley, Peter Murrell, } \\
\text { and Randi Ryterman }\end{array}$ & Nov. 1998 \\
\hline $\begin{array}{l}\text { No. 71: Giving Credit Where Credit Is Due: The Changing Role of } \\
\text { Rural Financial Institutions in China }\end{array}$ & $\begin{array}{l}\text { Albert Park, Loren Brandt, and } \\
\text { John Giles }\end{array}$ & Mar. 1997 \\
\hline $\begin{array}{l}\text { No. 70: Privatization Versus Competition: Changing Enterprise } \\
\text { Behavior in Russia }\end{array}$ & John S. Earle and Saul Estrin & $\begin{array}{l}\text { Spring } \\
1997\end{array}$ \\
\hline $\begin{array}{l}\text { No. 69: Russian Managers under Storm: Explicit Reality and Implicit } \\
\text { Leadership Theories (A Pilot Exploration) }\end{array}$ & Igor Gurkov & Oct. 1998 \\
\hline $\begin{array}{l}\text { No. 68: The Political Economy of Central-Local Relations in China: } \\
\text { Inflation and Investment Controls During the Reform Era }\end{array}$ & Yasheng Huang & $\begin{array}{l}\text { Spring } \\
1997\end{array}$ \\
\hline $\begin{array}{l}\text { No. 67: Between Two Coordination Failures: Automotive Industrial } \\
\text { Policy in China with a Comparison to Korea }\end{array}$ & Yasheng Huang & $\begin{array}{l}\text { Spring } \\
1997\end{array}$ \\
\hline $\begin{array}{l}\text { No. } 66 \text { Published in: Post-Soviet Geography and Economics, "Red } \\
\text { Executives in Russia's Transition Economy." Vol. 27, No. 10, Nov. } \\
\text { 1996, pp. 633-651. }\end{array}$ & Susan J. Linz & Jan. 1997 \\
\hline $\begin{array}{l}\text { No. } 65 \text { Published in: Industrial and Corporate Change, "On the } \\
\text { Sequencing of Privatization in Transition Economies." Vol. 7, No. 1, } \\
1998 .\end{array}$ & $\begin{array}{l}\text { Gautam Ahuja and Sumit K. } \\
\text { Majumdar }\end{array}$ & Apr. 1997 \\
\hline $\begin{array}{l}\text { No. 64: Published in: Journal of Law and Economics, "Foreign } \\
\text { Ownership and Profitability: Property Rights, Control and the } \\
\text { Performance of Firms in Indian Industry" 42(1), Apr. 1999, pp. 209-38. }\end{array}$ & $\begin{array}{l}\text { Pradeep K. Chhibber and Sumit } \\
\text { K. Majumdar }\end{array}$ & Apr. 1997 \\
\hline
\end{tabular}




\begin{tabular}{|c|c|c|}
\hline No. 63: How Taxing Is Corruption on International Investors? & Shang-Jin Wei & Feb. 1997 \\
\hline $\begin{array}{l}\text { No. 62: What Can We Learn from the Experience of Transitional } \\
\text { Economies with Labour Market Policies? }\end{array}$ & Tito Boeri & 1997 \\
\hline $\begin{array}{l}\text { No. 61: Published in: Accounting Organizations and Society, } \\
\text { "Economic Transition, Strategy and the Evolution of Management } \\
\text { Accounting Practices: The Case of India" 24(5,6), Jul/Aug 1999, pp. } \\
\text { 379-412. }\end{array}$ & $\begin{array}{l}\text { Shannon W. Anderson and } \\
\text { William N. Lanen }\end{array}$ & Apr. 1997 \\
\hline $\begin{array}{l}\text { No. 60a: Enterprise Investment During the Transition: Evidence from } \\
\text { Czech Panel Data }\end{array}$ & Lubomír Lizal and Jan Svejnar & Dec. 1997 \\
\hline $\begin{array}{l}\text { No. 59: Published in: Journal of Law, Economics, and Organization, } \\
\text { "Institutional Environment, Community Government, and Corporate } \\
\text { Governance: Understanding China's Township-Village Enterprises." } \\
\text { 14(1), Apr. 1998, pages 1-23 }\end{array}$ & Jiahua Che and Yingyi Qian & Apr. 1997 \\
\hline No. 58: From the Grabbing Hand to the Helping Hand & Jiahua Che & June 2000 \\
\hline $\begin{array}{l}\text { No. 57: Published in: Brookings Papers on Economic Activity, "The } \\
\text { Unofficial Economy in Transition." 1: } 1998 .\end{array}$ & $\begin{array}{l}\text { Simon Johnson, Daniel } \\
\text { Kaufmann, and Andrei Schleifer }\end{array}$ & June 1997 \\
\hline No. 56: Taxes and Government Incentives: Eastern Europe vs. China & Roger H. Gordon and David D. Li & Apr. 1997 \\
\hline No. 55: Corruption and Reform & Susanto Basu and David Li & June 1996 \\
\hline $\begin{array}{l}\text { No. 54: Decentralization and the Macroeconomic Consequences of } \\
\text { Commitment to State-Owned Firms }\end{array}$ & Loren Brandt and Xiaodong Zhu & June 1997 \\
\hline $\begin{array}{l}\text { No. 53: Published in: The International Journal of Industrial } \\
\text { Organization, "Competitive Shocks and Industrial Structure: The Case } \\
\text { of Polish Manufacturing." Aug., 1999. . }\end{array}$ & $\begin{array}{l}\text { Pankaj Ghemawat and Robert E. } \\
\text { Kennedy }\end{array}$ & May 1997 \\
\hline $\begin{array}{l}\text { No. 52: Published in: The Quarterly Journal of Economics, "Insecure } \\
\text { Property Rights and Government Ownership of Firms." May, } 1998 .\end{array}$ & Jiahua Che and Yingyi Qian & May 1997 \\
\hline No. 51: Incentives, Scale Economies, and Organizational Form & $\begin{array}{l}\text { Eric Maskin, Yingyi Qian, and } \\
\text { Chenggang Xu }\end{array}$ & May 1997 \\
\hline $\begin{array}{l}\text { No. 50: Published in: Post-Soviet-Affairs, "End of the Tunnel? The } \\
\text { Effects of Financial Stabilization in Russia" Apr.-June 1997, pages 105- } \\
33\end{array}$ & $\begin{array}{l}\text { Barry W. Ickes, Peter Murrell, } \\
\text { and Randi Ryterman }\end{array}$ & 1997 \\
\hline $\begin{array}{l}\text { No. 49: The Evolution of Bank Credit Quality in Transition: Theory and } \\
\text { Evidence from Romania }\end{array}$ & $\begin{array}{l}\text { Enrico C. Perotti and Octavian } \\
\text { Carare }\end{array}$ & Oct. 1996 \\
\hline $\begin{array}{l}\text { No. 48: Where Do the Leaders Trade? Information Revelation and } \\
\text { Interactions Between the Segments of Czech Capital Markets }\end{array}$ & $\begin{array}{l}\text { Jan Hanousek and Libor } \\
\text { Nemecek }\end{array}$ & May 1997 \\
\hline $\begin{array}{l}\text { No. 47: Firms' Heterogeneity in Transition: Evidence from a Polish } \\
\text { Panel Data Set }\end{array}$ & $\begin{array}{l}\text { Irena Grosfeld and Jean-François } \\
\text { Nivet }\end{array}$ & May 1997 \\
\hline No. 46: Strategic Creditor Passivity, Regulation, and Bank Bailouts & Janet Mitchell & May 1997 \\
\hline $\begin{array}{l}\text { No. 45a: Published in: Journal of Public Economics, "Tax Rights in } \\
\text { Transition Economies: A Tragedy of the Commons." 76, 2000, pp. 369- } \\
397\end{array}$ & Daniel M. Berkowitz and Wei Li & Sept. 1997 \\
\hline $\begin{array}{l}\text { No. 44a: The Information Content of Stock Markets: Why do Emerging } \\
\text { Markets have Synchronous Stock Price Movements? (forthcoming in } \\
\text { the Journal of Financial Economics). }\end{array}$ & $\begin{array}{l}\text { Randall Morck, Bernard Yeung, } \\
\text { and Wayne Yu }\end{array}$ & Feb. 1999 \\
\hline $\begin{array}{l}\text { No. 43: Agency in Project Screening and Termination Decisions: Why } \\
\text { Is Good Money Thrown After Bad? }\end{array}$ & Chong-en Bai and Yijiang Wang & May 1997 \\
\hline $\begin{array}{l}\text { No. 42: Published in: Economics of Transition, "Channels of } \\
\text { Redistribution: Inequality and Poverty in the Russian Transition." Vol. } 7 \\
\text { (2) } 1999 .\end{array}$ & $\begin{array}{l}\text { Simon Commander, Andrei } \\
\text { Tolstopiatenko, and Ruslan } \\
\text { Yemtsov }\end{array}$ & May 1997 \\
\hline $\begin{array}{l}\text { No. 41: Published in: Economics of Transition, "Labour Market } \\
\text { Characteristics and Profitability: Econometric Analysis of Hungarian } \\
\text { Exporting Firms, 1986-1995" 6(1), May 1998, pages 145-62 }\end{array}$ & László Halpern and Gabor Korosi & May 1997 \\
\hline $\begin{array}{l}\text { No. 40: Published in: the Harvard Law Review, "The Tragedy of the } \\
\text { Anticommons: Property in the Transition from Marx to Markets." Jan. } \\
\text { 1998. }\end{array}$ & Michael Heller & Feb. 1997 \\
\hline No. 39: Privatization and Managerial Efficiency & $\begin{array}{l}\text { Olivier Debande and Guido } \\
\text { Friebel }\end{array}$ & May 1997 \\
\hline
\end{tabular}




\begin{tabular}{|c|c|c|}
\hline $\begin{array}{l}\text { No. } 38 \text { Published in: The Quarterly Journal of Economics, } \\
\text { "Disorganization." Vol. 112, No. 4, Nov. 1997, pp. 1091-1126. }\end{array}$ & $\begin{array}{l}\text { Olivier Blanchard and Michael } \\
\text { Kremer }\end{array}$ & Jan. 1997 \\
\hline $\begin{array}{l}\text { No. 37: Published in: Economics of Transition, "Transition and the } \\
\text { Output Fall." 7(1), 1999, pages 1-28. }\end{array}$ & $\begin{array}{l}\text { Gérard Roland and Thierry } \\
\text { Verdier }\end{array}$ & Mar. 1997 \\
\hline $\begin{array}{l}\text { No. 36: Restructuring an Industry During Transition: A Two-Period } \\
\text { Model }\end{array}$ & Richard Ericson & Sept. 1996 \\
\hline No. 34: The East-West Joint Venture: BC Torsion Case Study & $\begin{array}{l}\text { Sonia Ferencikova and Vern } \\
\text { Terpstra }\end{array}$ & Dec. 1998 \\
\hline $\begin{array}{l}\text { No. } 33 \text { Published in: Journal of Comparative Economics, "Quantifying } \\
\text { Price Liberalization in Russia." Vol. 26, No. 4, Dec. 1998, pp. 735-737. }\end{array}$ & $\begin{array}{l}\text { Daniel Berkowitz, David DeJong, } \\
\text { and Steven Husted }\end{array}$ & Dec. 1998 \\
\hline No. 32: What Can North Korea Learn from China's Market Reforms? & John McMillan & Sept. 1996 \\
\hline $\begin{array}{l}\text { No. 31: Published in: China-Economic-Review, "Towards a Model of } \\
\text { China as a Partially Reformed Developing Economy Under a } \\
\text { Semifederalist Government." 9(1), Spring 1998, pages 1-23. }\end{array}$ & Yijiang Wang and Chun Chang & Mar. 1997 \\
\hline $\begin{array}{l}\text { No. 30: Convergence in Output in Transition Economies: Central and } \\
\text { Eastern Europe, } 1970-1995\end{array}$ & Saul Estrin and Giovanni Urga & Feb. 1997 \\
\hline $\begin{array}{l}\text { No. 29: Published in: Economics of Transition, "Altered Band and } \\
\text { Exchange Volatility." Volume 6, no. 1, 1998, 173-181. }\end{array}$ & Evzen Kocenda & Mar. 1997 \\
\hline $\begin{array}{l}\text { No. 28: Published in: Quarterly Journal of Economics, "Public Versus } \\
\text { Private Ownership of Firms: Evidence from Rural China." Volume 113, } \\
\text { no. 3, Aug. 1998, 773-808. }\end{array}$ & Hehui Jin and Yingyi Qian & Jan. 1997 \\
\hline $\begin{array}{l}\text { No. 27: East-West Joint Ventures in a Transitional Economy: The Case } \\
\text { of Slovakia }\end{array}$ & Sonia Ferencikova & Mar. 1997 \\
\hline $\begin{array}{l}\text { No. 26: Published in Economic Analysis "Behavior of a Slovenian Firm } \\
\text { in Transition" Vol. 1, no. 1, 1998, 57-73. }\end{array}$ & Janez Prasnikar & Feb. 1997 \\
\hline $\begin{array}{l}\text { No. 25: Cultural Encounters and Claims to Expertise in Postcommunist } \\
\text { Capitalism }\end{array}$ & Michael D. Kennedy & Feb. 1997 \\
\hline $\begin{array}{l}\text { No. 24: ZVU a.s.: Investment Funds on the Board of Directors of an } \\
\text { Engineering Giant }\end{array}$ & Tory Wolff & Aug. 1995 \\
\hline $\begin{array}{l}\text { No. 23: The Role of Investment Funds in the Czech Republic (joint } \\
\text { publication with Czech Management Center) }\end{array}$ & Dusan Triska & June 1996 \\
\hline $\begin{array}{l}\text { No. 22: Czech Investment Fund Industry: Development and Behaviour } \\
\text { (joint publication with Czech Management Center) }\end{array}$ & Richard Podpiera & May 1996 \\
\hline $\begin{array}{l}\text { No. 21: Restructuring of Czech Firms: An Example of Gama, a.s. (joint } \\
\text { publication with Czech Management Center) }\end{array}$ & Antonin Bulin & June 1996 \\
\hline $\begin{array}{l}\text { No. 20: YSE Funds: A Story of Czech Investment Funds (joint } \\
\text { publication with Czech Management Center) }\end{array}$ & Michal Otradovec & Nov. 1995 \\
\hline $\begin{array}{l}\text { No. 19: První Investicni a.s., The First Investment Corporation (joint } \\
\text { publication with Czech Management Center) }\end{array}$ & Jaroslav Jirasek & Aug. 1995 \\
\hline $\begin{array}{l}\text { No. 18: PPF a.s., The First Private Investment Fund (joint publication } \\
\text { with Czech Management Center) }\end{array}$ & Michal Otradovec & Nov. 1995 \\
\hline $\begin{array}{l}\text { No. } 17 \text { Published in: Post-Soviet Geography and Economics, "Russia's } \\
\text { Managers in Transition: Pilferers or Paladins?" 37(7) (Sept. 1996), pp. } \\
\text { 397-426. }\end{array}$ & Susan J. Linz and Gary Krueger & Nov. 1996 \\
\hline $\begin{array}{l}\text { No. 16: Banks in Transition-Investment Opportunities in Central } \\
\text { Europe and Russia, Edited Transcript from } 31 \text { May } 1996 \text { Conference in } \\
\text { New York City }\end{array}$ & $\begin{array}{l}\text { With commentary and edited by } \\
\text { Anna Meyendorff }\end{array}$ & Jan. 1997 \\
\hline $\begin{array}{l}\text { No. 15: Marketing in Transitional Economies: Edited Transcript \& } \\
\text { Papers from } 1 \text { Apr. } 1996 \text { Conference in Ann Arbor, Michigan }\end{array}$ & $\begin{array}{l}\text { Compiled by The Davidson } \\
\text { Institute }\end{array}$ & Dec. 1996 \\
\hline $\begin{array}{l}\text { No. 14: Pensions in the Former Soviet Bloc: Problems and Solutions. } \\
\text { Published by Council on Foreign Relations. "The Coming Global } \\
\text { Pension Crisis" New York, } 1997\end{array}$ & Jan Svejnar & Nov. 1996 \\
\hline $\begin{array}{l}\text { No. 13: Enterprise Restructuring and Performance in the Transition. } \\
\text { Forthcoming in Financial Systems in Transition: The Design of } \\
\text { Financial Systems in Central Europe eds. Anna Meyendorff and Anjan } \\
\text { Thakor. }\end{array}$ & $\begin{array}{l}\text { Lubomir Lizal, Miroslav Singer, } \\
\text { and Jan Svejnar }\end{array}$ & Dec. 1996 \\
\hline
\end{tabular}


Davidson Institute Working Papers are available at: www.wdi.bus.umich.edu

\begin{tabular}{|c|c|c|c|}
\hline \multicolumn{2}{|c|}{$\begin{array}{l}\text { No. } 12 \text { Published in: Journal of International Marketing, "Executive } \\
\text { Insights: Marketing Issues and Challenges in Transitional Economies." } \\
\text { Vol. 5, No. 4, 1997, pp. 95-114. Also published in: Marketing Issues in } \\
\text { Transitional Economies ed. Rajeev Batra. }\end{array}$} & Rajeev Batra & Apr. 1997 \\
\hline \multicolumn{2}{|c|}{$\begin{array}{l}\text { No. 11: Worker Trust and System Vulnerability in the Transition from } \\
\text { Socialism to Capitalism }\end{array}$} & Andrew Schotter & Aug. 1996 \\
\hline \multicolumn{2}{|c|}{$\begin{array}{l}\text { No. } 10 \text { Published in: Comparative Economic Studies, "Russian Firms in } \\
\text { Transition: Champions, Challengers, and Chaff." Vol. 39, No.2, } \\
\text { Summer 1997, pp. 1-36. }\end{array}$} & Susan J. Linz & July 1996 \\
\hline \multicolumn{2}{|l|}{$\begin{array}{l}\text { No. 9: Corporate Debt Crisis and Bankruptcy Law During the } \\
\text { Transition: The Case of China }\end{array}$} & David D. Li and Shan Li & Dec. 1995 \\
\hline \multicolumn{2}{|c|}{$\begin{array}{l}\text { No. } 8 \text { Published in: Journal of Comparative Economics, "A Theory of } \\
\text { Ambiguous Property Rights in Transition Economies: The Case of the } \\
\text { Chinese Non-State Sector." Vol. 23, No. 1, Aug. 1996, pp. 1-19. }\end{array}$} & David D. Li & June 1996 \\
\hline \multicolumn{2}{|c|}{$\begin{array}{l}\text { No. 7: The Foreign Economic Contract Law of China: Cases and } \\
\text { Analysis }\end{array}$} & Dong-lai Li & June 1993 \\
\hline \multicolumn{2}{|c|}{$\begin{array}{l}\text { No. 3: Bank Privatization in Hungary and the Magyar Kulkereskedelmi } \\
\text { Bank Transaction }\end{array}$} & $\begin{array}{l}\text { Kormend } \\
\text { tterly }\end{array}$ & May 1996 \\
\hline $\begin{array}{l}\text { Replacing No. 1: Journal of Comparative Economics } \\
\text { Symposium on "Bank Privatization in Central Europe and } \\
\text { Russia." Vol. 25, No. 1, Aug. } 1997 .\end{array}$ & \multicolumn{2}{|c|}{$\begin{array}{l}\text { "Bank Privatization in Transitional } \\
\text { Economies," Roger Kormendi and Edward } \\
\text { Snyder. }\end{array}$} & Aug. 1997 \\
\hline $\begin{array}{l}\text { Replacing No. 2: Journal of Comparative Economics } \\
\text { Symposium on "Bank Privatization in Central Europe and } \\
\text { Russia." Vol. 25, No. 1, Aug. } 1997 .\end{array}$ & \multicolumn{2}{|c|}{$\begin{array}{l}\text { "Transactional Structures of Bank } \\
\text { Privatizations in Central Europe and } \\
\text { Russia," Anna Meyendorff and Edward A. } \\
\text { Snyder. }\end{array}$} & Aug. 1997 \\
\hline $\begin{array}{l}\text { Replacing No. 4: Journal of Comparative Economics } \\
\text { Symposium on "Bank Privatization in Central Europe and } \\
\text { Russia." Vol. 25, No. 1, Aug. } 1997 .\end{array}$ & \multicolumn{2}{|c|}{$\begin{array}{l}\text { "Bank Privatization in Poland: The Case of } \\
\text { Bank Slaski," Jeffery Abarbaness and John } \\
\text { Bonin. }\end{array}$} & Aug. 1997 \\
\hline $\begin{array}{l}\text { Replacing No. 5: Journal of Comparative Economics } \\
\text { Symposium on "Bank Privatization in Central Europe and } \\
\text { Russia." Vol. 25, No. 1, Aug. } 1997 .\end{array}$ & \multicolumn{2}{|c|}{$\begin{array}{l}\text { "Bank Privatization in Post-Communist } \\
\text { Russia: The Case of Zhilsotsbank," Jeffery } \\
\text { Abarbanell and Anna Meyendorff }\end{array}$} & Aug. 1997 \\
\hline $\begin{array}{l}\text { Replacing No. 6: Journal of Comparative Economics } \\
\text { Symposium on "Bank Privatization in Central Europe and } \\
\text { Russia." Vol. 25, No. 1, Aug. } 1997 .\end{array}$ & \multicolumn{2}{|c|}{$\begin{array}{l}\text { "The Czech Republic's Commercial Bank: } \\
\text { Komercni Banka," Edward A. Snyder and } \\
\text { Roger C. Kormendi. }\end{array}$} & Aug. 1997 \\
\hline
\end{tabular}

